2015

\title{
Gentrified Sustainability: Inequitable Development and Seattle's Skewed Riskscape
}

Troy D. Abel

Western Washington University, troy.abel@wwu.edu

Jonah White

Western Washington University

Follow this and additional works at: https://cedar.wwu.edu/hcop_facpubs

Part of the Environmental Health and Protection Commons, and the Inequality and Stratification Commons

\section{Recommended Citation}

Abel, T.D. and White, J. (2015) ‘Gentrified sustainability: inequitable development and Seattle’s skewed riskscape', Interdisciplinary Environmental Review, Vol. 16, Nos. 2/3/4, pp.124-157.

This Article is brought to you for free and open access by the Huxley College on the Peninsulas at Western CEDAR. It has been accepted for inclusion in Huxley College on the Peninsulas Publications by an authorized administrator of Western CEDAR. For more information, please contact westerncedar@wwu.edu. 


\title{
Gentrified sustainability: inequitable development and Seattle's skewed riskscape
}

\author{
Troy D. Abel ${ }^{*}$
}

Huxley College of the Environment Peninsulas Program,

Western Washington University,

PO Box 1699, Poulsbo,

WA 98370 , USA

Email: Troy.Abel@wwu.edu

*Corresponding author

\section{Jonah White}

Department of Environmental Studies, Western Washington University,

516 High Street, MS 9085,

Bellingham, WA 98225, USA

Email: jonah.white@wwu.edu

\begin{abstract}
This paper examines the tensions of sustainable development in Seattle, Washington, a commonly recognised urban environmental leader. Drawing on the perspective of sustainability as a conflicted process, this research expected a negative relationship between gentrification and environmental justice when affluent residents outcompete less affluent ones for neighbourhoods with fewer environmental hazards. The methods combine geographic cluster analysis and longitudinal air toxic emission comparisons to analyse socioeconomic changes in Seattle Census block-groups between 1990, 2000, and 2009 coupled with measures of relative potential risk and pollution volume. The property and development conflicts embedded within sustainability lead to pollution exposure risk and socioeconomic vulnerability converging in the same areas and reveal one of the 'Emerald City's' significant environmental challenges. Inequitable development and environmental injustice remain overlooked dimensions of sustainability that interdisciplinary research should address.
\end{abstract}

Keywords: gentrification; sustainability; environmental justice; inequitable development.

Reference to this paper should be made as follows: Abel, T.D. and White, J. (2015) 'Gentrified sustainability: inequitable development and Seattle's skewed riskscape', Interdisciplinary Environmental Review, Vol. 16, Nos. 2/3/4, pp.124-157.

Biographical notes: Troy D. Abel is an Associate Professor and an Academic Program Director in Huxley College of the Environment Peninsulas Program, Western Washington University. His teaching and research interests focus on the dynamic tensions of environmental science and democratic politics in a variety of arenas including climate risk governance, environmental justice, and political biogeography. 
Jonah White is a Geography Instructor and a Research Analyst in Western Washington University, Huxley College of the Environment. He holds an MS in Geography and his research and teaching interests focus on physical and human geography and the contradictions of urban development and planning, gentrification, and inequitable development.

This paper is a revised and expanded version of a paper entitled 'Gentrified sustainability: inequitable development and Seattle's riskscape', presented at the Just Sustainability: Hope for the Commons, Seattle University, Seattle, WA, August 7-9, 2015.

\section{Sustainability and interdisciplinary research}

Sustainability strategies now join a whole range of environmental policies that contrast with the centralised, command-and-control style of regulation developed during the 70s and 80s. First conceived at the international level in the United Nations' World Commission on Environment and Development (WCED, 1987) report Our Common Future, sustainability was defined as: "development that meets the needs of the present without compromising the ability of future generations to meet their own needs" (p.43). Sustainability is now a prominent feature of urban strategies and popularised in a threecircle Venn diagram sometimes called the "triple-bottom" line (Elkington, 1998; Savitz, 2013; Willard, 2012). This is where environmental strategies achieve a nexus of ecology, economy, and equity $\left(\mathrm{E}^{3}\right)$.

Conversely, a growing body of work raises important limitations in the popular conceptions of sustainability. Agyeman, Bullard and Evans (2002) offered one exploration of the intersections between environmental justice and sustainability concluding that: "the two discourses and traditions of environmental justice and sustainability have developed in parallel and, although they have touched, there has been insufficient interpenetration of values, framings, ideas, and understandings" (p.88). More pessimistically, Dobson $(1998,2003)$ predicted that social justice and environmental sustainability were incompatible. Likewise, another scholar described a serious dissonance between the discourse of a 'Just Sustainability' paradigm and an 'Environmentalist-Stewardship Sustainability' tradition (Agyeman, 2005, 91). Others focus on the tensions or contests embedded within the sustainability or sustainable development concept itself (Connelly, 2007; McManus, 1996; Williams and Millington, 2004).

For instance, Campbell (1996) did not conceive of an intersecting Venn diagram of economy, ecology, and equity where a harmonious centre produces sustainability. "Planners have to redefine sustainability, since its current formulation romanticises our sustainable past and is too vaguely holistic" (Campbell, 1996, 296). Therefore, he identified a triangle where economy, ecology, and equity are points divided by three dynamic conflicts confronting sustainability planning. First, the resource conflict pits economic growth and efficiency against environmental protection. The second division is a development conflict between social justice, economic opportunity, and income equality versus environmental protection. Third, a property conflict divides economic growth and efficiency from social justice, economic opportunity, and income equality. Our analysis focuses on the latter two with equity as the pivot point (see Figure 1). 
Figure 1 Sustainability and its conflicts (adapted from Campbell, 1996) (see online version for colours)

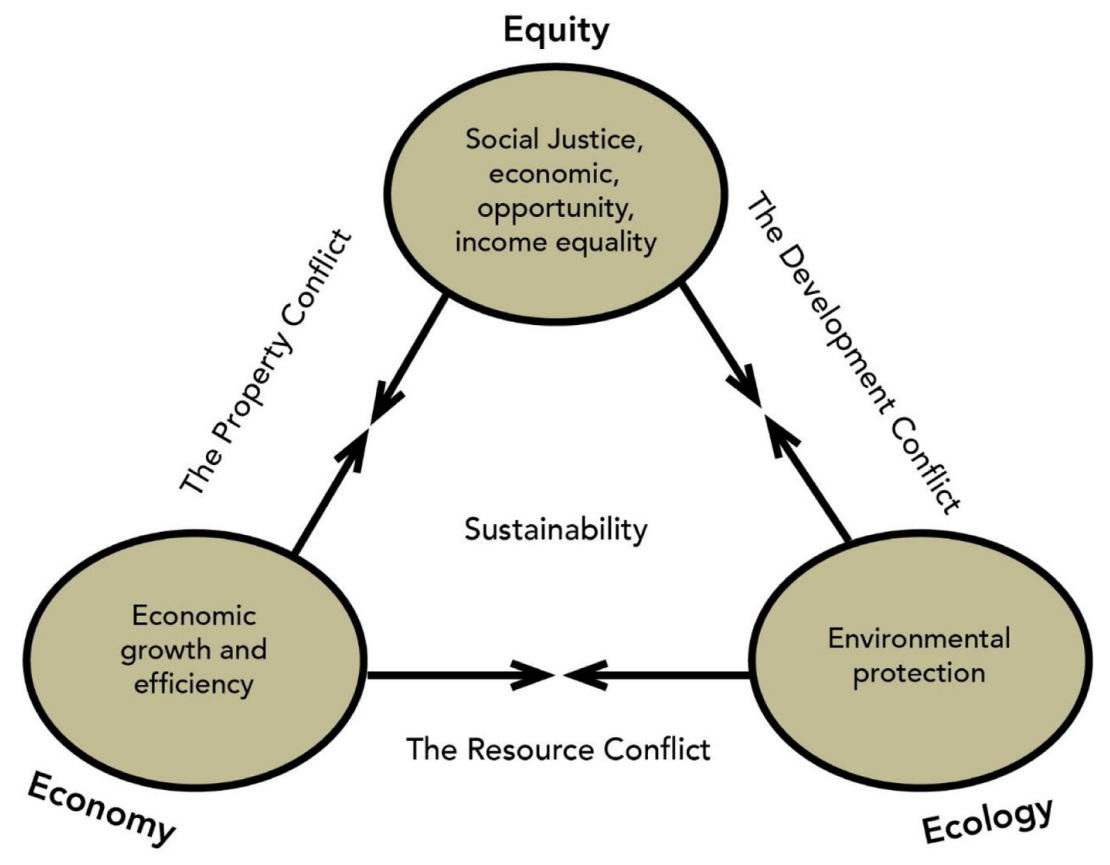

Source: adapted from Campbell, 1996

Our research uses Seattle, WA as a case study to examine the complex intersections of sustainability in an urban geography. Seattle is often touted as a hallmark of sustainability because it launched the first US sustainability indicators program (Atkinson, 1996; Karlenzig, 2008), ranked first in Portney's (2003) rankings of cities taking sustainability seriously, third in another sustainable cities ranking (Karlenzig, 2007), and received the US Environmental Protection Agency's (EPA) 2003 Climate Protection Award (US EPA, 2003). Conversely, a small collection of voices question Seattle's environmental reputation. Klingle's (2007) book on the city reveals a history of environmental degradation and urban inequity. Likewise, Sanders (2010) alluded to a side of Seattle that is not "...a story of black and white, of total success or total failure of ideals, but rather one as gray as the recycled water that Ecotopians sprinkled on their gardens. The down side of this greener urbanism may have been its tendency to reinforce a trend toward a more fractured landscape in a city that would become increasingly out of reach to working and middle-class families" (214).

For instance, in recent work, researchers identified how US cities are being divided by the 'creative class' (Florida, 2002) and included analysis for New York, Los Angeles, Chicago, Dallas, Houston, Philadelphia, Washington, DC, Miami, Atlanta, Boston, San Francisco, and Detroit (Florida et al., 2014). In short, high paid professional 'knowledge workers' outcompete the service and working class for proximity to urban amenities like proximity to transit lines, universities, and natural areas. Our paper adds Seattle to this kind of research while also achieving an interdisciplinary approach combining sociology's concern with stratification, economic geography's attention to urban 
development, and environmental science's focus on toxic pollution risks. This paper explores three hypotheses. First, gentrification processes in Seattle are expected to be widespread and result in a geography of increasingly inequitable development. Conversely, "...the creation and maintenance of economically and socially diverse communities that are stable over the long term, through means that generate a minimum of transition costs that fall unfairly on lower income residents" (Kennedy and Leonard, $2001,4)$ was one of the first definitions of equitable development. But it requires, according to one urban practitioner, “...the promotion and management of economic growth that maximises benefits for residents of low-income communities throughout metropolitan regions and assures their voice in the development process" (Blackwell, $2000,1283)$. Second, Seattle's industrial air pollution risk sources are expected to be unequally hazardous and unevenly dispersed across the city. Third, socially vulnerable neighbourhoods are expected to bear more of the proximity burden of the city's riskiest industrial facilities.

\subsection{The Emerald city, sustainability, and the equity blind spot}

In many ways, Seattle, Washington is a world-class example of a postindustrial and sustainable city. Seattle is surrounded by the picturesque Salish Sea, evergreen forests, and snowcapped peaks. Microsoft, Starbucks, and Amazon make their home here along with the philanthropy of the Bill and Melinda Gates Foundation and its efforts to fund global justice projects. Yet, in 2006 the median home value in Seattle was 7.7 times more than the median household income (Cohen, 2007). According to one observer, "the everincreasing concentration of wealth could mean Seattle will become more and more the gilded city of the upper-middle and upper classes" (McGee, 2007, 236). As home buyers compete in this market, middle and lower income households are squeezed out of many neighbourhoods in Seattle. According to a Seattle Times analysis, "the only area in Seattle where median-income folks could afford the median-priced house was the residential/industrial/commercial swath south of downtown that includes Georgetown and South Park" (Rhodes and Mayo, 2006). Seattle exemplifies a dividing city and the contested geographies of postindustrial development that have been overlooked.

Likewise, the equity aspect of sustainability has not been seriously addressed in most cities according to one observer. "As practiced in most cities, equity issues do not appear to be an integral part of cities' definitions of sustainability" (Portney, 2003, 175). Moreover, most sustainable development indicators (SDI) or frameworks provide inadequate equity measures (Warner, 2000), lose the social dimension (Vifell and Soneryd, 2012), or miss equity completely (Cuthill, 2010; Mitchell, 1996). For instance, a recent sustainability journal devoted an entire issue to this "missing pillar" of social sustainability (Boström, 2012). In a discourse analysis of San Francisco Bay Area city officials, researchers found most respondents emphasised urban design, civic engagement, and traditional economic development instead of social equity (Zeemering, 2009).

Also, researchers conducted a wider study of more than 200 medium to large cities and concluded that cities are more commonly engaged in the environmental aspects of sustainability and "There is little evidence that cities are connecting sustainability to equity and social justice issues" (Saha and Paterson, 2008, p.21). Moreover, in an empirical literature review of publications on local sustainability, equity was found to have mostly been ignored (Saha, 2009). In sum, social equity is largely missing from 
North American research and practice in sustainability while garnering some attention from urban scholars in the UK (Bramley and Power, 2009; Bramley et al., 2009; Burton, 2000; Dempsey, Brown and Bramley, 2012; Jenks and Jones, 2010). We address this gap with our Seattle case study by explicitly examining socioeconomic stratification longitudinally in the city and its relationship with gentrification and pollution source proximity.

However, a large literature in geography has dealt with the property dialectic (equity vs. economy) and its urban dynamics through the concepts of gentrification and inequitable development. Gentrification became a prominent US urbanisation pattern during the 90s (Smith, 1996; Lees, Slater and Wyly, 2008; Ley, 1996; Wyly and Hammel, 2004) contributing to property competition in the urban core. Some claim that the process is more good than bad (Ellen and O'Regan, 2011; McKinnish, Walsh and White, 2010), that the concept is often underspecified (Atkinson, 2003; Hamnett, 1991; Vigdor, Massey and Rivlin, 2002), and still others emphasise gentrification's negative impacts and its role in undermining equitable development (Smith, 2000). It is a much broader conception of development that is growing in the planning and geography literature (Bates and Zapata, 2014; Blackwell, 2000, 2003; Blackwell and Bell, 2005; Vojnovic, 2013) and among practitioners (Eley, 2010, 2013; EPA, 2015). For instance, one Seattle planner defined equitable development as: "Public and private investments in neighbourhood to meet the needs of those affected by poverty, communities of colour, and historically marginalized communities" (Liu, 2015).

We consider the opposite which is defined as the emergence and growth of economically and socially divided communities with transition costs falling unfairly on lower-income and non-White residents according to Kennedy and Leonard (2001). For instance, researchers found that gentrified neighbourhoods in the core across the US actually attracted more than twice the capital reinvestment than the suburbs resulting in "islands of decay in seas of renewal" (Wyly and Hammel, 1999). One kind of decay island has been described as environmental 'hot spots,' or “...locales where pollutant concentrations are substantially higher than concentrations indicated by ambient outdoor monitors located in adjacent or surrounding areas" (National Research Council, 2004, 274). Research on the unequal formation of proximity to air toxics hot spots is an overlooked issue in many urban environmental justice studies. Our focus here is on property as a scarce resource and investment in one area versus disinvestment in another. Smith $(1979,1987)$ popularised the 'rent gap' process behind gentrification's dynamics.

Simply put, the 'rent gap' describes the disparity between the actual ground rent received under current land-use designation and the higher, potential ground rent if another type of land-use were implemented (e.g. re-zoning, infill, subdividing). The rent gap forms as the initial investment under a particular type of land-use begins to return smaller profits and lessens the incentive of the landholder to upkeep and maintain the land under its current use. Over time, this disinvestment depresses land values to the point where reinvestment or land-use conversion becomes profitable. This reinvestment can not only gentrify residents out of areas, but also contributes to inequitable development. Past scholars have linked this cycle, and its effects, to the broader process of cities transforming from industrial to postindustrial landscapes (Hamnett, 2003; Hamnett and Whitelegg, 2007; Ley, 1981, 1996). 


\subsection{Development's conflict and environmental injustice}

"If, as some argue, environmental protection is a luxury of the wealthy, then environmental racism lies at the heart of the development conflict" according to Campbell $(1996,299)$. A theory of environmental inequality formation (EIF) is central to the challenge of environmental racism and injustice. "EIF occurs when different stakeholders struggle for access to scarce resources within the political economy, and the benefits and costs of those resources become distributed unevenly" (Pellow, 2000, 589). In a seminal study, sociologist Robert Bullard (1983) introduced policy makers and social scientists to a distributional scrutiny of race and pollution that would become commonly known as environmental justice analysis. Landfills in Houston, TX were found to be located in predominately African-American neighbourhoods leading to the conclusion that institutionalised housing market discrimination, a lack of zoning, and government permitting decisions led to the cities "... black neighbourhoods becoming the "dumping ground' for the area's solid waste" (Bullard, 1983, 273). Likewise, the US General Accounting Office (GAO, 1983, now the Government Accountability Office) studied waste landfill sitting in eight Southern states and found that on average, three out of four of these environmental hazards were located in predominately minority communities. These two studies set the stage for the watershed study of environmental justice in the US.

In a national analysis of zip codes nationwide, research indicated that areas with landfills had, on average, double the percent minority of landfill-free zip codes (UCC, 1987). While a few studies would challenge these early investigations (Anderton et al., 1994; Davidson and Anderton, 2000; Yandle and Burton, 1996), a majority of studies supported the conclusion that a geography of environmental injustice was common across the US (Bryant and Mohai, 1992; Bullard, 1990, 1994; Cutter and Solecki, 1996; Goldman, 1991; Goldman and Fitton, 1994; Mitchell, Thomas and Cutter, 1999; Mohai and Saha, 2006, 2007; Morello-Frosch, Pastor and Sadd, 2001; Neumann, Forman and Rothlein, 1998; Pollock and Vitas, 1995; Sadd et al., 1999; Szasz and Meuser, 2000). In a seminal meta-analysis of 49 studies over a decade, one reviewer concluded that racebased environmental inequities were ubiquitous (Ringquist, 2005).

Many subsequent studies have found that the spatial distributions of pollution hazards and socially vulnerable populations (poor and minority) cluster together leading to environmental inequalities as a major feature of America's urban geographies in Boston (Krieg, 1995), Cleveland (Bowen et al., 1995), Detroit (Downey, 2006); Gary (Hurley, 1995); Los Angeles (Boer et al., 1997; Boone and Modarres, 1999; Burke, 1993; Morello-Frosch et al., 2002; Pastor, Morello-Frosch and Sadd, 2005; Pastor, Sadd and Hipp, 2001; Pastor, Sadd and Morello-Frosch, 2004; Pulido, 2000; Pulido, Sidawi and Vos, 1996), Portland (Elliott and Frickel, 2013; Stroud, 1999); St. Louis (Abel, 2008), Tampa Bay (Chakraborty and Bosman, 2010), and Toronto (Kershaw et al., 2013). An unequal riskscape has also been identified in Seattle with one study finding that the city's "...pollution riskscape and urban development burdens were skewed toward the city's most socially vulnerable residents" (Abel and White, 2011, S252).

However, many of the most recognised empirical studies maintained a methodological commitment to the analysis of statistical averages. Such analyses overlook extreme skewness that characterises the worst cases of environmental injustice. The majority of EJ studies only crudely describe how socially vulnerable groups are disproportionately closer to hazards such as landfills, hazardous waste sites, incinerators, and industrial emissions. But proximity and release amounts tell us nothing about relative 
chemical toxicity and who's exposed to them. Hazardous waste buried in landfills, shipped in tanker trucks, or released from a smokestack can vary widely in their toxicity.

As one group of EPA researchers noted, "the human health impacts of carcinogens and noncarcinogens...can differ by up to seven and eight orders of magnitude. That is, a single pound of the most toxic chemicals...is toxicologically equivalent to one hundred million pounds of the least toxic of these substances" (Bouwes, Hassur, and Shapiro, 2001, 3-4). Because not all pollution is created equally, models of the average proximity of pollution and socially vulnerable populations tell decision-makers little about relative-risk that would inform policies to address the worst pollution first (Abel, 2008). Therefore, the second part of this analysis joins a growing number of studies using a simulated risk-weighted measure of facility air pollution hazard that can reveal potential toxic hotspots and their proximity to socially vulnerable communities (Ash and Fetter, 2004; Gilbert and Chakraborty, 2011; Downey et al., 2008; Downey and Hawkins, 2008; Morello-Frosch, Pastor and Sadd, 2001; Sadd et al., 2011; Shapiro, 2005; Sicotte and Swanson, 2007; Toffel and Marshall, 2004).

\section{Methods and results}

Despite a diversity of studies over several decades, several gaps remain in environmental justice scholarship. In particular, environmental justice research tends to focus on the existence of environmental inequality rather than its formation (Pellow, 2000). Our project offers an empirical application of the varied theoretical development around environmental and health inequity as a sociohistorical process. Moreover, our study also addresses several critical gaps in data and research on proximity to high risk facilities, the structure of socioeconomic inequity, and their spatial convergence in urban geographies. First, the field has been limited by an over reliance on narrowly constructed empirical models that use the geography of averages where pollution and minorities coincide. Likewise, sustainability research, and sustainability indicators in particular offer citywide accountings at too coarse a resolution to discern neighbourhood-level social and environmental inequities.

Second, many scholars continue to argue over the appropriate spatial-scale of analysis. The earliest and most influential studies relied on zip codes while others claimed that census tracts were more appropriate. Others advocated census block-groups (CBGs) while many recent studies use concentric buffers around environmental hazards. Likewise, scholars have fixated on the longitudinal dynamics of industrial siting (Oakes, Anderton, and Anderson 1996) rather than the evolving inequities of urban development. Our Seattle research moves beyond these debates by producing a longitudinal and multiscaled picture of socioenvironmental vulnerability with a combination of data from 568 CBGs and 113 Toxics Release Inventory (TRI) facilities and the simulated air toxics exposures from pollution emissions.

\subsection{Seattle's inequitable geography}

We compiled demographic information on Seattle's CBGs from the 1990 and 2000 censuses plus data from the 5-year estimate of the 2009 American Community Survey. We included that measures commonly utilised by urban geographers to characterise gentrification and analysed these measures using the methods of urban factorial ecology 
(see Lyon and Driskell, 2011 for a review). Gentrification research often uses combinations of variables from a few broad categories, namely population, socioeconomic, and housing measures. Population measures utilised frequently encompass age structures and racial/ethnic compositions (Bostic and Martin, 2003; Hudspeth, 2003; Ley, 1996; Bondi, 1999). Theory also describes the significance of neighbourhood age structure because children under 18 years old are negatively associated with gentrification (Hudspeth, 2003) while 25-34 years old young adults are considered to be the driving force in the new, creative, postindustrial economy taking shape in North America (Ley, 1996).

Other socioeconomic indicators common to gentrification research include metrics of income and poverty, education, and occupation (Heidkamp and Lucas, 2006; Ley, 1996; Hammel and Wyle, 1996). This series of variables is frequently linked with the transformation towards postindustrial society wherein overall social status (educational level and professional occupations) is expected to increase as well as associated incomes and spending power, facilitating the ability of individuals to actively participate in gentrification (Ley, 1996). However, this restructuring is also accompanied by an increase in a variety of lower wage-paying occupations in the service sector of the economy, signifying higher poverty levels, and thus, resulting in greater income polarisation between educated professionals and hourly service sector workers (Bell, 1973).

Housing measures are also part of many gentrification studies that include house prices and values, rent prices, home ownership, and household structure (Hammel and Wyly, 1996; Heidkamp and Lucas, 2006; Morrill, 2008; Smith, 1979). According to Smith (1979), as residential structures in the inner-city experience perpetual disinvestment, the values become so depressed that housing renovation and rehabilitation become profitable ventures. These depressed values pave the way for gentrification and, as the neighbourhood and residences experience new capital investment, the improvements lead to an increase in demand that fuels competition in these locations and can amplify rising housing costs. Thus the homeownership rate is a reliable proxy in gentrification research as only affluent and financially secure households are able to afford the higher housing costs (Heidkamp and Lucas, 2006). Additionally, changing household structure, particularly non-family households, can indicate gentrification as young, singles, unrelated roommates, or unmarried couples share the costs and expenses to rent or own desirable housing in a popular neighbourhood (Morrill, 2008).

Following several classic urban analyses with more recent studies, we utilise a form of cluster analysis described as factorial social ecology (Berry, 1971; Haynes, 1971; Janson, 1980; Fischer et al., 2004; Pacione, 2005). It is the geographic application of factor analysis and seeks to reduce a larger set of social, economic, and demographic measures into smaller groups of variables that describe the salient spatial characteristics of a city's CBGs. From the larger set of indicators, this approach attempts to establish sets of basic dimensions in socioecological differentiation; to reach empirical generalisations about these dimensions; and, to develop a theory of socioecological structure and change in terms of these dimensions (Janson, 1980). Since, gentrification is considered to encompass change in any number of combinations of indicators, we first compiled and factor analysed 12 variables from the broad categories of population, socioeconomic and housing measures to better understand the change in socioecological structure in each of the 568 CBGs in Seattle for the 1990, 2000, and 2009 time periods. 
Factor analysis in the form of principal components analysis (PCA) is an effective data reduction technique well-suited for the exploratory purpose of our Seattle study, because the method produces uncorrelated components (sets of variables) from the larger data set, determines the relationship between the variables and components, and assigns component scores indicating the value for each CBG on each component (Abel and White, 2011; Cadwallader, 1996; Kim and Mueller, 1978; Wyly, 1999). As such, this technique allows us to characterise the components and their relationship to gentrification and provides a framework for understanding the pattern of gentrification in Seattle.

Next, cluster analysis was used to group together block-groups that share similar component scores from each PCA (Aldenderfer and Blashfield, 1984). This method differentiated areas that experienced gentrification from those that have not and identified where significant changes in socioeconomic character occurred. The most appropriate clustering method for this project was a minimum distance hierarchical technique, called Ward's method, which maximised between-group differences while minimising withingroup differences (Lattin, Carroll, and Green, 2003). This method resulted in small sized clusters (as few block-groups as possible) with substantial homogeneity. Thus, blockgroups that experienced significant change in the form of gentrification are welldifferentiated from those that experienced other trajectories.

The census data were obtained from GeoLytics, Inc., a firm which has produced specialised data products that normalise CBGs to the year 2000 boundaries. We extracted block-group data to compare the longitudinal shift in Seattle neighbourhoods. Built from census blocks, CBGs are the second finest spatial unit available from the US Census and typically contain 600 to 3,000 people (US Department of Commerce, 1994). Our Seattle dataset included 568 CBGs obtained from the compact disc titled, CensusCD 1990 Long Form in 2000 Boundaries, Census 2000, and the 5-year estimate of the 2009 American Community Survey. In the tradition of neo-structural urban geography (Harvey, 1989) and following the work of Morrill $(2004 ; 2008)$ with Seattle's census tracts, we utilised a finer resolution of data and the multivariate statistical methods of classic factorial social ecology to explore the hypothesis that gentrification processes would be widespread in Seattle and result in a shrinking landscape of affordable housing.

\subsection{Cluster analysis}

We computed three different PCAs reflecting each cross-section: 1990, 2000, and 2009. A series of PCAs identified seven underlying factors that shaped the social geography of Seattle. These seven factors were entered into a cluster analysis and Figure 2 displays a 15-cluster characterisation of Seattle's shifting socioeconomic strata. First, PCA on Seattle's 1990 CBG data yielded a three-factor solution reminiscent of applied factorial social ecology studies (Shevky and Bell, 1955; Abu-Lughod, 1969; Berry, 1985; Berry and Rees, 1969; Schmid and Tagashira, 1964). Its three factors included socioeconomic status, race/ethnicity, and household structure, which explained about $73 \%$ of the variance in Seattle CBGs. The socioeconomic factor produced high loadings on percentage of college graduates, percentage of professional occupations, median household income, median contract rent, and median house value. With strong positive loadings, this factor is indicative of a structural divide between the creative and working classes in Seattle. In the second factor, racial divides are manifest with the percentage of White alone inversely related to Black or Asian alone and the percentage at or below the poverty level. The third factor highlights a divide between traditional home-owning 
families and younger, unrelated residents who value urban living and amenities. The percentage of population age 25-34 loads together with non-family households while both are inversely correlated to median household income and homeownership rates.

Figure 2 Factorial ecology for Seattle, 1990-2009

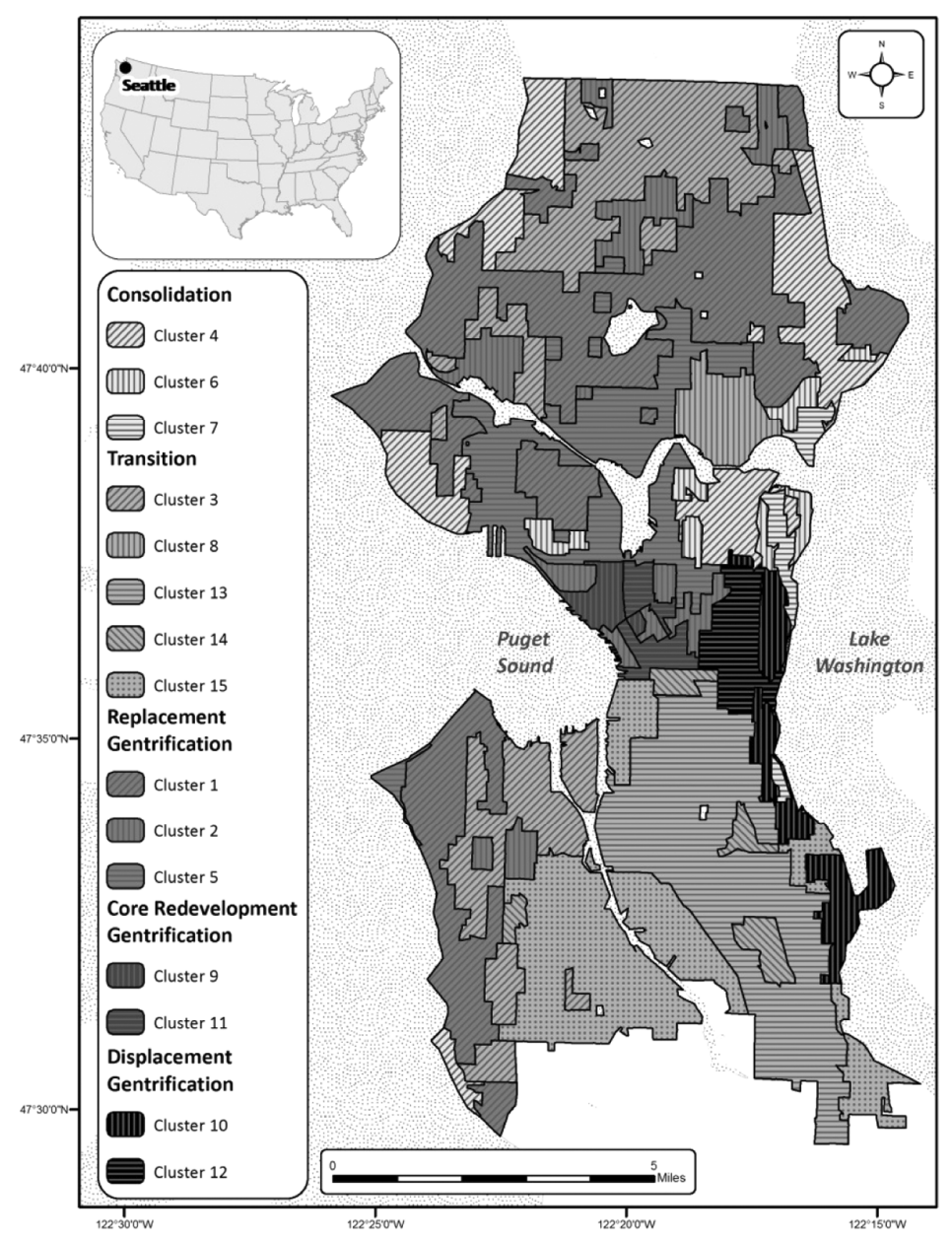

Second, the 2000 PCA results are consistent with more recent literature identifying just two factors reflecting an urban structure shaped mostly by socioracial status and household structure. Accounting for $65 \%$ of the variance in the arrangement of Seattle's urban landscape, the first factor represents a convergence of socioeconomic status and ethnicity. Factor 1 produced positive loadings for the percentage of college graduates, percentage of professional employment, median household income, median contract rent, median house value, and percentage of White. Variables with negative loadings on factor 1 included percentage Black alone, Asian alone, and residents at or below the poverty line. This structure reflected an emerging divide between the labor forces, yet the individual importance of median household income, median contract rent, and median house value was superseded by college graduates and professional occupation. Factor 2 is 
identical to factor 3 from 1990 and indicated that urban amenities as viewed by different types of households continue to be significant in the city's structural form.

Third, the 2009 PCA continued to indicate an urban structure shaped by socioracial status and household structure. Accounting for $59 \%$ of the variance in the spatial arrangement of Seattle, the first factor produced positive loadings for the percentage of college graduates, percentage of professional employment, median household income, median house value, and percentage White. Variables with negative loadings on factor 1 included percentage Black alone, Asian alone, and residents at or below the poverty line. This structure reflected a deepening divide between White and non-White populations in terms of professional status and affluence.

Factor 2 is nearly identical to factor 3 in 1990, and factor 2 in 2000 indicating that urban amenities for varying households continue to be significant in the city's structural form. The percentage of population age 25-34 loads negatively with non-family households and both are inversely correlated with median household income and rates of homeownership. In fact, the relative importance of the proportion of population age 25-34, median household income, and homeownership rates increased since 1990 indicating a significant disparity between traditional home-owning families and younger residents. We then utilised the combination of factors from 1990, 2000, and 2009 in a hierarchical cluster analysis of Seattle's CBGs.

The results of the cluster analysis yielded groupings of CBGs with similar values on the seven factors derived from our PCA and summarised in Table 1. Like Morrill (2004; 2008), we explored multiple cluster solutions and found a 15-cluster solution to be the most coherent ordering of Seattle's urban structure considering quantitative relationships as well as historical geographies of locally recognised neighbourhoods. A 16th cluster was excluded from statistical estimations because it encompassed the industrial district of Harbor Island at the mouth of the Duwamish River containing no residences.

Clusters 1, 2, and 5 were dispersed throughout the city and represented areas of increased professional status and affluence. Clusters 4, 6, and 7 captured some of the most affluent neighbourhoods and their coveted viewsheds. Cluster 3 included neighbourhoods with changing population compositions and household structures. Cluster 8 is one of the most concentrated and compact areas encompassing the city's largest higher educational institution, the University of Washington. Clusters 9 and 11 covered downtown and the central business district (CBD) and exhibited significant increases in home values. Cluster 10 was another viewshed area with upper class residential homes and Cluster 12 contained a historically African-American neighbourhood regionally known as the Central District. Clusters 13 and 14 were majority-minority neighbourhoods dominated by lower middle class residents with low professional status. Cluster 15 was a racially diverse working class neighbourhood intertwined with Seattle's industrial district.

Seven of Seattle's 15 clusters experienced gentrification confirming our first hypothesis concerning inequitable development. A closer look at socioeconomic trends in cluster 15, from Tables 2-4, illustrates this pattern. The working class neighbourhoods in cluster 15 transformed into majority non-White that increased from 36.4 to $50.6 \%$ between 1990 and 2000. The cluster also had an increase in Black residents between 1990 and 2000 while most clusters in the city lost African-Americans. The Asian population increased at a faster rate in cluster 15 but this area's racial transformation 
reversed. In 2009, cluster 15 returned to a majority White population and the proportion of Black and Asian residents fell slightly.

Table 1 Gentrification typology

\begin{tabular}{|c|c|}
\hline \multicolumn{2}{|c|}{ Consolidation clusters } \\
\hline 4 & $\begin{array}{l}\text { High social status; high income; high home ownership rate; high } \\
\text { average home; values }\end{array}$ \\
\hline 6 & $\begin{array}{l}\text { High social status; high income; above average home ownership; high } \\
\text { average home values }\end{array}$ \\
\hline 7 & $\begin{array}{l}\text { Highest social status; highest average home values; high home } \\
\text { ownership rate }\end{array}$ \\
\hline \multicolumn{2}{|c|}{ Transition clusters } \\
\hline 3 & $\begin{array}{l}\text { Increasing social status; middle income; young, nor-families; increasing } \\
\text { minorities }\end{array}$ \\
\hline 8 & $\begin{array}{l}\text { University District; college-educated professionals; young, non-families } \\
\text { in poverty }\end{array}$ \\
\hline 13 & $\begin{array}{l}\text { Asian influx; little change in social status (working-class); above } \\
\text { average home ownership }\end{array}$ \\
\hline 14 & $\begin{array}{l}\text { Asian influx; low social status (working-class); high poverty; low home } \\
\text { ownership }\end{array}$ \\
\hline 15 & $\begin{array}{l}\text { Minority mixing; little change in social status (working-class); above } \\
\text { average home ownership }\end{array}$ \\
\hline \multicolumn{2}{|c|}{$\begin{array}{l}\text { Replacement } \\
\text { gentrification clusters }\end{array}$} \\
\hline 1 & $\begin{array}{l}\text { Increased social status; above average incomes; increase in non- } \\
\text { families; above average home values; above average home ownership }\end{array}$ \\
\hline 2 & $\begin{array}{l}\text { Increasing social status; increase in young, non-families; primarily } \\
\text { renters }\end{array}$ \\
\hline 5 & $\begin{array}{l}\text { Increased social status; above average incomes; young, non-families; } \\
\text { above average home values; primarily renters }\end{array}$ \\
\hline \multicolumn{2}{|c|}{$\begin{array}{l}\text { Core redevelopment } \\
\text { gentrification clusters }\end{array}$} \\
\hline 9 & $\begin{array}{l}\text { Increased social status; increase in young population; increasing income; } \\
\text { increased home values; reduced poverty }\end{array}$ \\
\hline 11 & $\begin{array}{l}\text { Increasing social status; increased young, non-families; increased home } \\
\text { values }\end{array}$ \\
\hline \multicolumn{2}{|c|}{$\begin{array}{l}\text { Displacement } \\
\text { gentrification clusters }\end{array}$} \\
\hline 10 & $\begin{array}{l}\text { Increased social status; high income; reduced poverty; high home } \\
\text { values; considerable loss of Black population }\end{array}$ \\
\hline 12 & $\begin{array}{l}\text { Increasing social status; increasing income; increase in young, } \\
\text { non-families; reduced poverty; substantial loss of Black population } \\
\text { (Central District) }\end{array}$ \\
\hline
\end{tabular}


Table 2 Census block group trends: race and age

\begin{tabular}{|c|c|c|c|c|c|c|}
\hline \multirow[b]{2}{*}{ Cluster (n) } & \multicolumn{3}{|c|}{ Percent White alone } & \multicolumn{3}{|c|}{ Percent Black alone } \\
\hline & 1990 & 2000 & 2009 & 1990 & 2000 & 2009 \\
\hline $1(136)$ & 92.03 & 87.99 & 87.70 & 1.53 & 1.53 & 1.19 \\
\hline $2(45)$ & 80.21 & 73.48 & 74.80 & 8.16 & 6.99 & 5.98 \\
\hline $3(83)$ & 85.80 & 78.52 & 78.99 & 2.58 & 3.92 & 4.73 \\
\hline $4(43)$ & 92.29 & 89.14 & 87.99 & 1.82 & 1.37 & 1.74 \\
\hline $5(69)$ & 90.14 & 86.11 & 86.54 & 2.98 & 2.37 & 1.32 \\
\hline $6(13)$ & 91.59 & 87.70 & 86.14 & 1.66 & 1.99 & 2.83 \\
\hline $7(7)$ & 94.19 & 92.62 & 92.98 & 1.02 & 1.41 & 0.00 \\
\hline $8(16)$ & 72.87 & 68.80 & 64.78 & 3.80 & 2.98 & 3.62 \\
\hline $9(8)$ & 86.29 & 75.13 & 79.27 & 5.67 & 8.16 & 6.29 \\
\hline $10(19)$ & 56.91 & 64.81 & 74.20 & 30.38 & 19.66 & 9.60 \\
\hline $11(12)$ & 66.06 & 59.88 & 59.02 & 17.82 & 17.93 & 15.97 \\
\hline $12(23)$ & 26.06 & 42.32 & 51.80 & 65.32 & 41.36 & 32.78 \\
\hline $13(51)$ & 25.12 & 21.35 & 25.82 & 28.43 & 21.42 & 21.56 \\
\hline $14(12)$ & 22.09 & 14.60 & 20.88 & 32.40 & 24.45 & 29.00 \\
\hline $15(31)$ & 63.56 & 49.39 & 57.39 & 14.86 & 15.48 & 14.91 \\
\hline \multirow[t]{2}{*}{ Seattle city } & 75.96 & 71.78 & 71.63 & 10.21 & 8.44 & 7.68 \\
\hline & \multicolumn{3}{|c|}{ Percent Asian alone } & \multicolumn{3}{|c|}{ Percent age 25-34 } \\
\hline Cluster (n) & 1990 & 2000 & 2009 & 1990 & 2000 & 2009 \\
\hline $1(136)$ & 4.89 & 5.55 & 5.90 & 21.32 & 19.24 & 16.66 \\
\hline $2(45)$ & 8.04 & 10.36 & 10.53 & 26.97 & 29.37 & 36.28 \\
\hline $3(83)$ & 8.30 & 9.67 & 8.61 & 21.75 & 21.07 & 21.51 \\
\hline $4(43)$ & 5.22 & 5.93 & 6.32 & 13.50 & 10.63 & 8.00 \\
\hline $5(69)$ & 4.81 & 5.93 & 6.55 & 31.50 & 35.22 & 35.07 \\
\hline $6(13)$ & 5.51 & 6.28 & 5.76 & 23.06 & 23.35 & 19.81 \\
\hline $7(7)$ & 3.77 & 3.21 & 2.82 & 5.93 & 3.64 & 5.60 \\
\hline $8(16)$ & 20.28 & 20.42 & 22.40 & 25.32 & 22.83 & 17.10 \\
\hline $9(8)$ & 4.88 & 8.27 & 8.59 & 18.74 & 32.09 & 33.34 \\
\hline $10(19)$ & 10.90 & 9.24 & 8.79 & 15.04 & 15.84 & 9.04 \\
\hline $11(12)$ & 9.30 & 10.43 & 11.88 & 24.61 & 26.30 & 31.95 \\
\hline $12(23)$ & 5.80 & 5.34 & 4.61 & 20.79 & 22.12 & 23.03 \\
\hline $13(51)$ & 43.23 & 45.77 & 40.81 & 18.31 & 16.74 & 16.90 \\
\hline $14(12)$ & 38.48 & 48.14 & 41.18 & 15.61 & 12.00 & 14.63 \\
\hline $15(31)$ & 16.17 & 19.70 & 16.63 & 19.22 & 16.97 & 17.85 \\
\hline Seattle city & 11.19 & 12.55 & 12.79 & 21.73 & 21.71 & 21.73 \\
\hline
\end{tabular}


Inequitable development and Seattle's skewed riskscape

Table 3 Census block group trends: social status (adjusted to 2000 dollars)

\begin{tabular}{|c|c|c|c|c|c|c|}
\hline \multirow[b]{2}{*}{ Cluster (n) } & \multicolumn{3}{|c|}{ Median household income } & \multicolumn{3}{|c|}{ Percent at or below poverty } \\
\hline & 1990 & 2000 & 2009 & 1990 & 2000 & 2009 \\
\hline $1(136)$ & 66,319 & 80,943 & 84,943 & 5.08 & 4.94 & 6.04 \\
\hline $2(45)$ & 36,756 & 42,764 & 44,745 & 17.63 & 16.74 & 14.91 \\
\hline $3(83)$ & 53,047 & 59,363 & 60,579 & 8.01 & 9.41 & 9.46 \\
\hline $4(43)$ & 93,579 & 112,849 & 120,030 & 3.09 & 3.24 & 3.28 \\
\hline $5(69)$ & 51,557 & 64,828 & 64,854 & 10.51 & 8.79 & 9.28 \\
\hline $6(13)$ & 65,435 & 79,385 & 69,352 & 7.77 & 8.81 & 8.35 \\
\hline $7(7)$ & 163,602 & 174,088 & 220,113 & 1.75 & 1.36 & 1.45 \\
\hline $8(16)$ & 26,369 & 33,156 & 32,897 & 30.81 & 31.42 & 42.05 \\
\hline $9(8)$ & 26,278 & 42,464 & 45,790 & 20.86 & 17.84 & 18.24 \\
\hline $10(19)$ & 76,228 & 97,696 & 110,985 & 5.38 & 4.46 & 3.60 \\
\hline $11(12)$ & 22,779 & 24,444 & 27,488 & 30.64 & 38.97 & 37.05 \\
\hline $12(23)$ & 40,674 & 55,389 & 56,986 & 19.26 & 17.24 & 16.31 \\
\hline $13(51)$ & 46,649 & 54,139 & 50,176 & 16.37 & 14.06 & 15.96 \\
\hline $14(12)$ & 16,295 & 22,189 & 38,953 & 54.75 & 43.07 & 31.27 \\
\hline $15(31)$ & 50,133 & 58,404 & 60,029 & 13.15 & 12.25 & 15.77 \\
\hline \multirow[t]{2}{*}{ Seattle city } & 56,463 & 58,862 & 60,843 & 12.38 & 11.79 & 12.24 \\
\hline & \multicolumn{3}{|c|}{ Median contract rent } & \multicolumn{3}{|c|}{ Median house value } \\
\hline Cluster (n) & 1990 & 2000 & 2009 & 1990 & 2000 & 2009 \\
\hline $1(136)$ & 901 & 1,083 & 1,151 & 264,790 & 377,386 & 521,368 \\
\hline $2(45)$ & 724 & 869 & 843 & 143,438 & 244,756 & 344,576 \\
\hline $3(83)$ & 806 & 934 & 849 & 204,521 & 267,538 & 387,558 \\
\hline $4(43)$ & 1,147 & 1,313 & 1,408 & 422,480 & 551,004 & 727,137 \\
\hline $5(69)$ & 817 & 978 & 966 & 280,153 & 372,908 & 491,893 \\
\hline $6(13)$ & 896 & 1,028 & 1,089 & 537,429 & 625,285 & 716,785 \\
\hline $7(7)$ & 1,325 & 1,104 & 2,050 & 753,921 & $1,074,609$ & 990,929 \\
\hline $8(16)$ & 680 & 764 & 836 & 187,307 & 221,718 & 502,335 \\
\hline $9(8)$ & 596 & 908 & 973 & $15,357^{*}$ & 478,636 & 608,296 \\
\hline $10(19)$ & 877 & 1,171 & 1,462 & 292,178 & 441,584 & 624,453 \\
\hline $11(12)$ & 576 & 640 & 694 & 73,598 & 269,916 & 487,051 \\
\hline $12(23)$ & 685 & 858 & 983 & 167,535 & 309,960 & 436,804 \\
\hline $13(51)$ & 660 & 771 & 794 & 148,402 & 231,095 & 330,622 \\
\hline $14(12)$ & 260 & 317 & 397 & 96,350 & 223,391 & 325,573 \\
\hline $15(31)$ & 741 & 874 & 926 & 146,134 & 218,852 & 338,416 \\
\hline Seattle city & 815 & 928 & 1,024 & 239,198 & 334,105 & 446,900 \\
\hline
\end{tabular}

*Only 8 census block groups in cluster 9 and, in 1990, only 1 block group recorded a median house value of $\$ 122,855$. This value is distributed among the 8 block groups resulting in a median house value of $\$ 15,357$ in the cluster. 
Table 4 Census block group trends: professional status

\begin{tabular}{lccccccc}
\hline & \multicolumn{3}{c}{ Percent college graduates } & & \multicolumn{3}{c}{ Percent professional / managerial } \\
\cline { 2 - 3 } \cline { 7 - 8 } Cluster $(n)$ & 1990 & 2000 & 2009 & & 1990 & 2000 & 2009 \\
\hline $1(136)$ & 43.54 & 56.27 & 66.08 & & 43.01 & 56.70 & 62.99 \\
$2(45)$ & 32.54 & 42.97 & 50.82 & & 30.86 & 41.67 & 48.17 \\
$3(83)$ & 28.35 & 38.58 & 49.40 & & 30.23 & 42.50 & 48.69 \\
$4(43)$ & 57.32 & 67.85 & 71.36 & & 53.70 & 66.28 & 66.99 \\
$5(69)$ & 52.27 & 63.01 & 68.85 & & 42.41 & 57.30 & 60.56 \\
$6(13)$ & 65.21 & 71.80 & 74.26 & & 58.34 & 64.08 & 57.76 \\
$7(7)$ & 78.29 & 84.18 & 92.86 & & 69.94 & 73.01 & 77.22 \\
$8(16)$ & 60.46 & 65.91 & 64.85 & & 31.98 & 42.09 & 45.15 \\
$9(8)$ & 31.13 & 44.68 & 60.12 & & 31.33 & 49.13 & 59.02 \\
$10(19)$ & 47.53 & 61.29 & 69.54 & & 47.02 & 63.56 & 72.54 \\
$11(12)$ & 21.81 & 21.92 & 34.54 & & 20.73 & 34.65 & 43.13 \\
$12(23)$ & 22.47 & 38.08 & 49.05 & & 28.46 & 43.05 & 49.88 \\
$13(51)$ & 15.81 & 21.93 & 27.11 & & 17.91 & 27.20 & 30.48 \\
$14(12)$ & 7.93 & 12.18 & 24.86 & & 11.62 & 17.05 & 33.71 \\
$15(31)$ & 16.99 & 25.43 & 30.48 & & 19.61 & 30.91 & 37.99 \\
\hline Seattle city & 37.91 & 47.19 & 54.31 & 36.27 & 48.41 & 52.29 \\
\hline
\end{tabular}

Median household income in Cluster 15 remained below the city average in 1990, 2000, and 2009. While poverty declined between 1990 and 2000, it climbed from 12.3 to $15.8 \%$ between 2000 and 2009. Median house values increased at a higher rate than for the rest of the city (131.6 and $86.8 \%$ ) but remained more than $\$ 100,000$ below the median value of a Seattle home. Cluster 15's gap of college graduates compared to the rest of the city increased between 1990 and 2009. Seventeen percent of Cluster 15 held a college degree in 1990 while $37.9 \%$ was the city average (20.9\% difference). In $2009,30.5 \%$ of Cluster 15 residents held a college degree while the city average was $54.3 \%$ ( $23.8 \%$ difference). Cluster 13 displays a similar class contrast with the rest of the city while hosting a much larger share of Asian and Black residents. Both clusters had higher poverty rates than the rest of Seattle.

\subsection{Seattle's skewed riskscape}

To overcome the limited attention to environmental inequality formation and an emphasis on averages in environmental justice scholarship, we also described the spatial distribution of Seattle's relative risks associated with industrial air polluters located around the city. We first plotted the spatial location of the city's 113 TRI facilities with air emissions at three intervals: 1990, 2000, and 2009 (see Figures 3-5). TRI facilities include all industrial firms that are required by the EPA to voluntarily report the release of any toxic chemical into the environment if: 
1 it is in the following industrial sectors - manufacturing, metal mining, coal mining, electrical utilities, hazardous waste treatment and disposal facilities, chemical plants, petroleum plants and terminals, solvent recovery services, and federal facilities;

2 has 10 or more full-time employees; and

3 manufactures or processes more than 25,000 pounds or otherwise uses more than 10,000 pounds of any listed chemical during the calendar year.

Figure 3 Seattle's riskscape in 1990

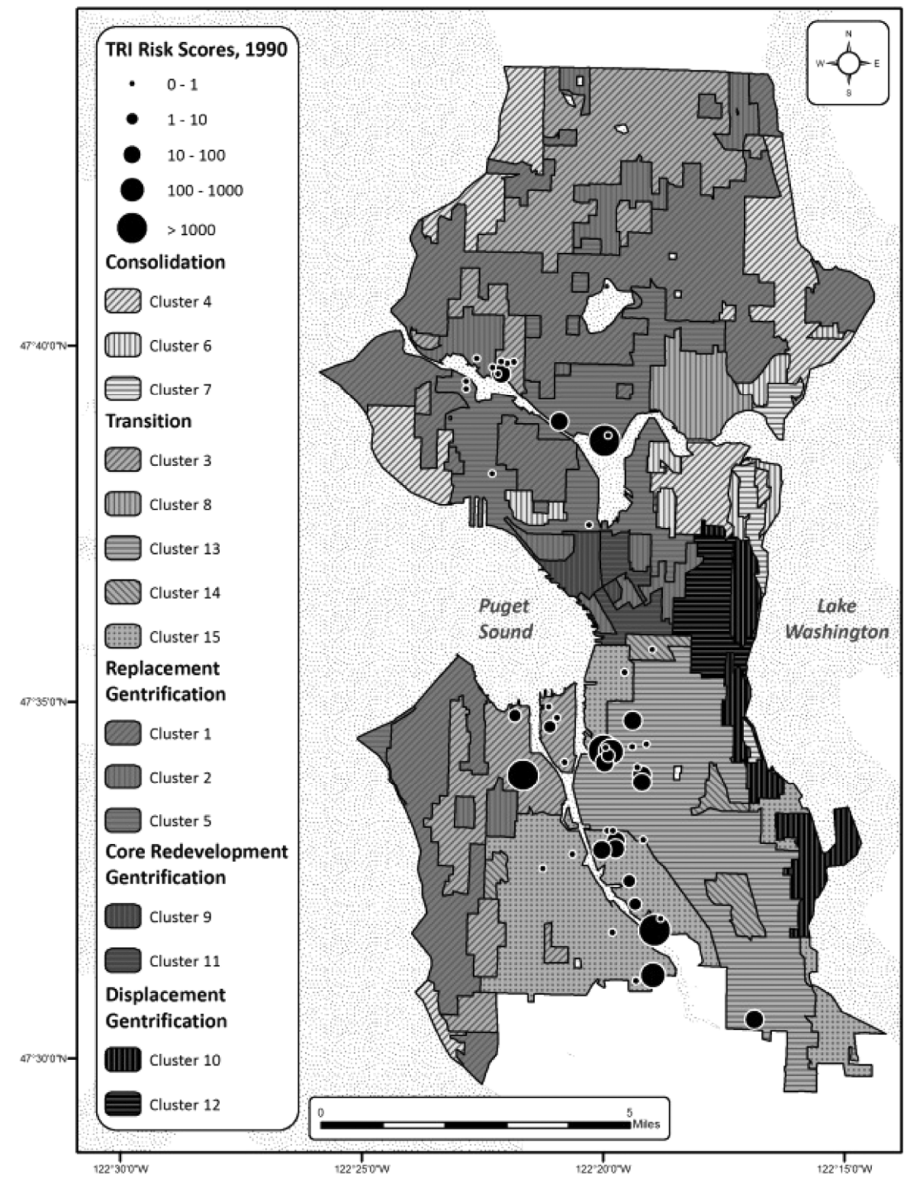

We then characterised the relative-risk of the air pollution from these facilities by simulating inhalation exposures with the Risk-Screening Environmental Indicators model (RSEI) from the US EPA's Office of pollution prevention and toxics (OPPT). The RSEI software begins with facilities reporting to the TRI who are required to report annually the toxic chemicals they release and the amounts. These release volumes are inputs into a steady-state Gaussian plume model that then simulates downwind pollutant concentrations from a stack or fugitive air source. Finally, a surrogate inhalation dose is estimated for neighbouring census populations. An indicator value is then produced that can be used to rank relative impacts by geography, industry, and facility (Schmidt, 2003). 
Figure 4 Seattle's riskscape in 2000

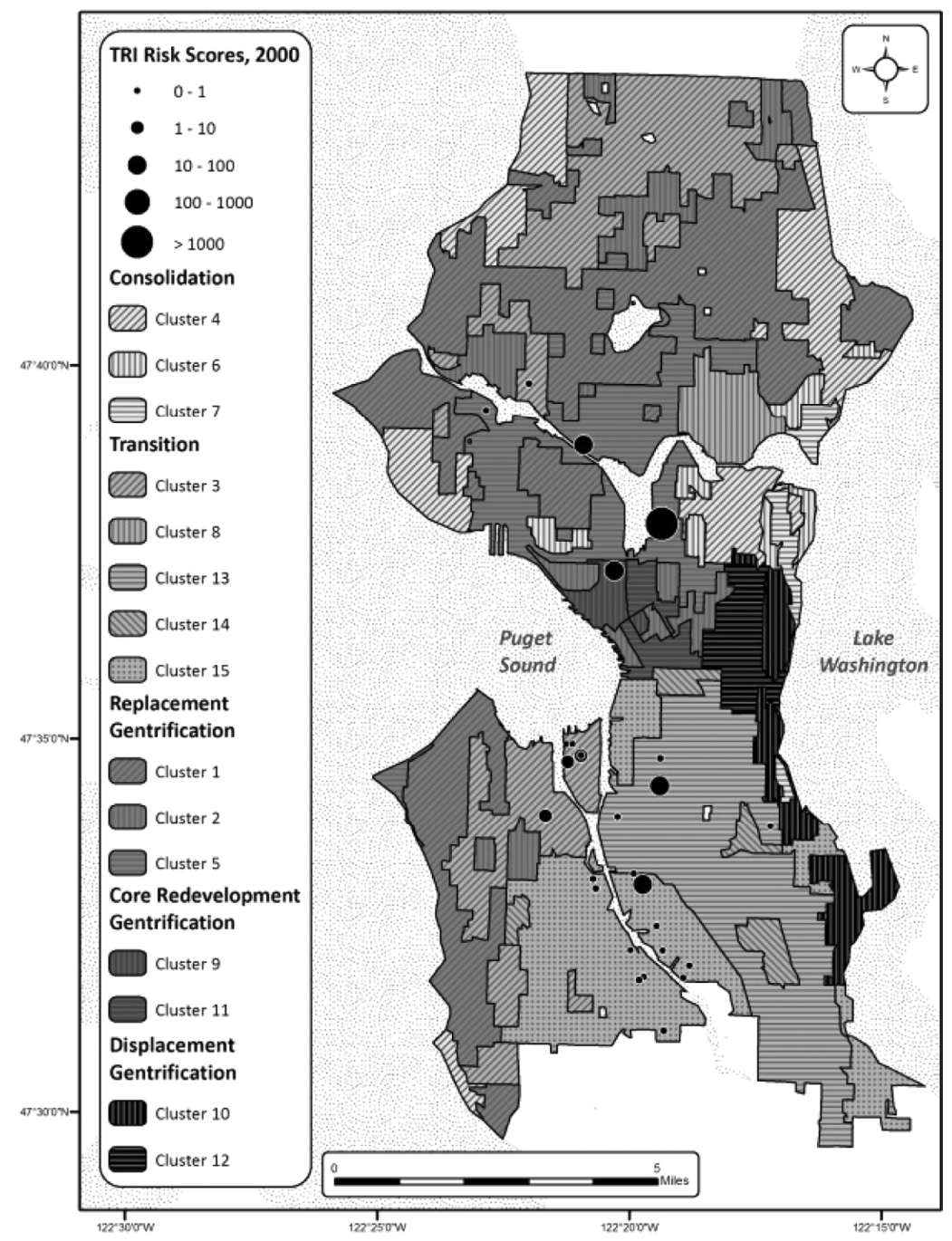

Table 5 displays the relative-risk indicator values for the 10 most hazardous industrial air pollution sources in Seattle for the single years 1990, 2000, and 2009 and then for all years (1990-2009). Air pollution volume dropped dramatically from over 2 million pounds in 1990 to less than 70,000 pounds in 2009; a decline of 97\%. The relative-risk scores also plunged from over 30 million to less than forty-thousand in 2009. Four TRI facilities in 1990 and six in 2009 produced 95\% of Seattle's relative air toxic risk exposure. Only one facility in 1990, PSF industries, accounted for 50\% of the city's relative-risk burden with just 7,205 pounds of toxic air emissions. A Boeing facility released over a million pounds of air emission while accounting for less than $7 \%$ of Seattle's simulated air toxic relative risk. In 2000 and 2009, Sound Propeller Services accounted for more than $70 \%$ of the relative air toxic emission risk with only 500 and 20 pounds of air releases, respectively. These were chromium and nickel compounds posing much higher risks than other chemicals even at much greater release volumes. 
Figure 5 Seattle's riskscape in 2009

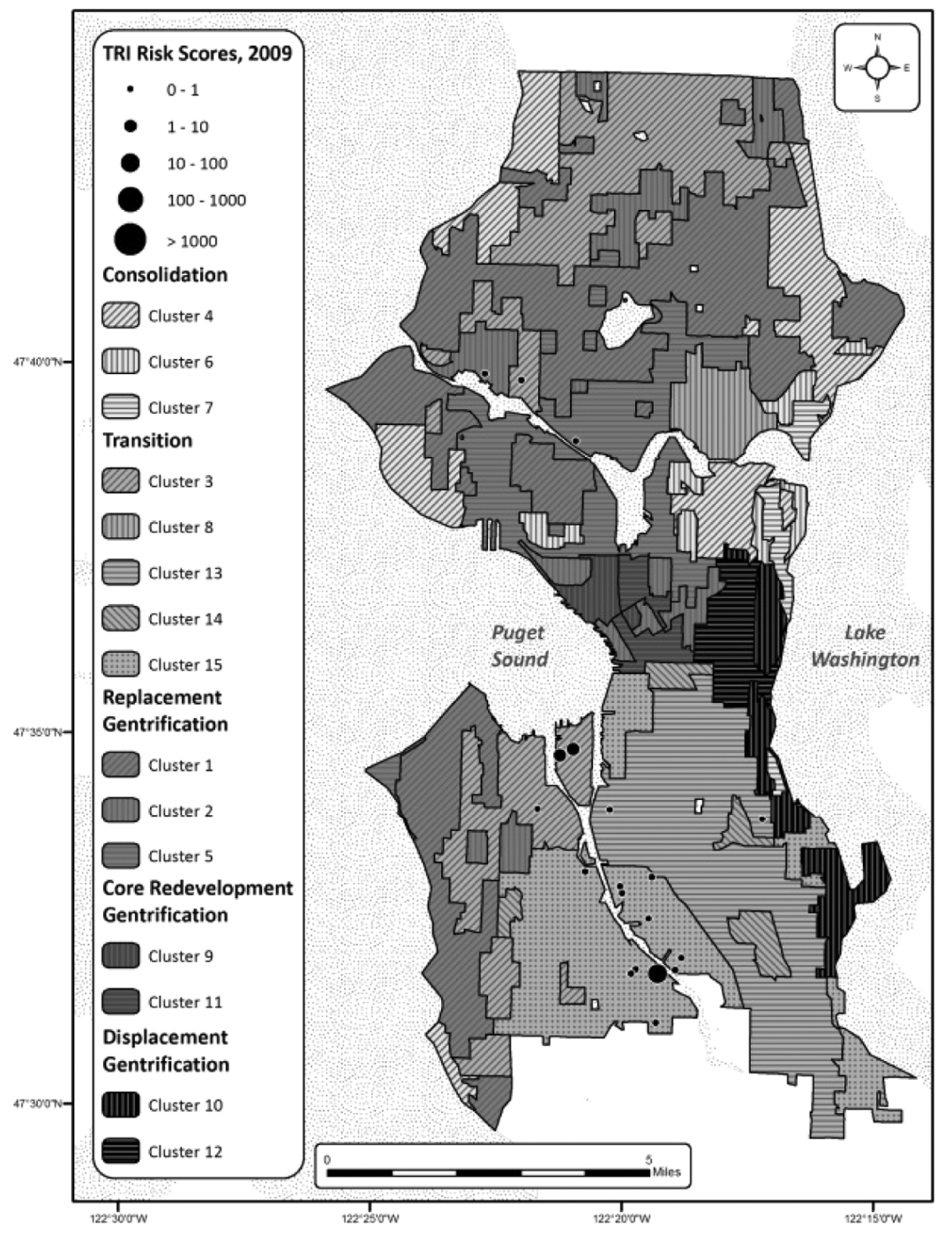

Table 5 also provides an accounting of the uneven clustering of Seattle's environmental inequality. Over the 20-year study period, six facilities were responsible for over $90 \%$ of Seattle's toxic risk exposure simulated from air pollution releases. In fact, three of the top 10 simulated air toxic risk producers were located in cluster 13 while two were located in cluster 15. Most (5) of Seattle's riskiest industrial polluters were located in cluster 13 in 1990, but in 2000, cluster 15 hosted three. By 2009, cluster 15 led all Seattle neighbourhoods in hosting risky industrial polluters with five of the top 10 . Cluster 13 hosted $50 \%$ of the air toxic exposure risk in 1990 while cluster 15 contained the one facility responsible for $76 \%$ of the city's pollution risk production in 2009 . Our third hypothesis was supported by data from 1990 and 2009, but not in 2000. Sound Propeller's former Lake Union location earned cluster 5 the top spot for simulated industrial air toxic exposure risk at the midpoint of our study period. 
Table 5 Seattle's 10 Highest Toxics Release Inventory (TRI) Air Pollution Exposure Risk Characterizations in 1990, 2000, 2009, and from 1990 to 2009

\begin{tabular}{|c|c|c|c|c|c|}
\hline Facility name & Cluster & Pounds & Risk value & Total risk \% & Cumulative risk, \% \\
\hline \multicolumn{6}{|c|}{1990} \\
\hline PSF INDUSTRIES INC. & 13 & 7,205 & $14,958,861.94$ & 49.01 & 49.01 \\
\hline AMERICAN TAR CO. & 5 & 1,255 & $11,670,515.74$ & 38.24 & 87.25 \\
\hline BOEING COMMERCIAL AIRPLANE PLANT 2 & 15 & $1,070,553$ & $1,740,279.18$ & 5.70 & 92.95 \\
\hline SEATTLE STEEL INC. & 3 & 44,100 & $1,395,724.49$ & 4.57 & 97.52 \\
\hline PRECISION ENGINEERING INC. & 15 & 250 & $211,857.68$ & 0.69 & 98.21 \\
\hline WESTERN STEEL CASTING CO. & 13 & 1,500 & $171,021.64$ & 0.56 & 98.77 \\
\hline DIETZGEN CORP. & 13 & 2,470 & $72,246.03$ & 0.24 & 99.01 \\
\hline NORTH STAR CASTEELPRODUCTS INC. & 13 & 1,000 & $67,406.67$ & 0.22 & 99.23 \\
\hline NORTHWEST PLATING CO. & 13 & 37,970 & $48,096.28$ & 0.16 & 9939 \\
\hline ASKO PROCESSING INC. & 5 & 16,291 & $36,669.09$ & 0.12 & 99.51 \\
\hline Top 10 facility totals & - & $1,182, \mathrm{~S} 94$ & $30,372,678.74$ & 99.51 & 99.51 \\
\hline All facility totals $(\mathrm{n}=58)$ & - & $2,478,741$ & $30,522,468.99$ & 100.00 & 100.00 \\
\hline \multicolumn{6}{|c|}{2000} \\
\hline SOUND PROPELLER SERVICES LAKE UNION & 5 & 500 & $640,879.60$ & 70.78 & 70.78 \\
\hline ALASKAN COPPER WORKS & 13 & 30 & $86,877.06$ & 9.59 & 80.37 \\
\hline WESCOR GRAPHICS CORP. & 9 & 18,240 & $63,903.48$ & 7.06 & 87.43 \\
\hline ASKO PROCESSING INC. & 5 & 9,925 & $50,952.00$ & 5.63 & 93.06 \\
\hline ART BRASS PLATING INC. & 15 & 17,820 & $46,732.50$ & 5.16 & 98.22 \\
\hline NUCOR STEEL SEATTLE 1NC & 3 & 45,224 & $7,457.97$ & 0.82 & 99.04 \\
\hline EQUILON ENTERPRISES LLC & 3 & 3,004 & $2,981.70$ & 0.33 & 9937 \\
\hline BP WEST COAST PRODUCTS CO. & 3 & 4,110 & $1,447.96$ & 0.16 & 99.53 \\
\hline VIOX CORP. & 15 & 238 & 791.27 & 0.09 & 99.62 \\
\hline BOEING COMMERCIAL AIRPLANE BOEING FIELD & 15 & 32,602 & 672.59 & 0.07 & 99.69 \\
\hline Top 10 facility totals & - & 131,693 & $902,696.13$ & 99.69 & 99.69 \\
\hline All facility totals $(\mathrm{n}=34)$ & & 285,737 & $905,478.23$ & 100.00 & 100.00 \\
\hline \multicolumn{6}{|c|}{2009} \\
\hline SOUND PROPELLER SERVICES SOUTH PARK & 15 & 20 & $26,871.40$ & 76.26 & 76.26 \\
\hline EQUILON ENTERPRISES LLC & 3 & 4,000 & $3,620.06$ & 10.27 & 86.53 \\
\hline BP WEST COAST PRODUCTS CO. & 3 & 4,551 & $1,299.92$ & 3.69 & 90.22 \\
\hline SAINT-GOBAIN CONTAINERS 1 NC. & 15 & 383 & 792.87 & 2.25 & 92.47 \\
\hline BOEING COMMERCIAL AIRPLANE BOEING FIELD & 15 & 7,600 & 694.61 & 1.97 & 94.44 \\
\hline PUGET SOUND COATINGS & 15 & 36,931 & 500.85 & 1.42 & 95.86 \\
\hline NUCOR STEEL SEATTLE INC & 3 & 1,438 & 496.68 & 1.41 & 97.27 \\
\hline RUDD CO INC. & 3 & 5,615 & 196.15 & 0.56 & 97 A3 \\
\hline ASH GROVE CEMENT CO. & 13 & 135 & 111.06 & 032 & 98.15 \\
\hline LAFARGE NORTH AMERICA & 15 & 43 & 7931 & 0.23 & 9837 \\
\hline Top 10 facility totals & - & 60,716 & $34,662.91$ & 98.37 & 9837 \\
\hline All facility totals $(\mathrm{n}=22)$ & - & 68,580 & 35.237 .07 & 100.00 & 100.00 \\
\hline \multicolumn{6}{|c|}{ 1990-2009 } \\
\hline PSF INDUSTRIES INC. & 13 & 15,864 & $35,725,552.16$ & 50.65 & 50.65 \\
\hline AMERICAN TAR CO. & 5 & 1,255 & $11,670,515.74$ & 16.54 & 67.19 \\
\hline ALASKAN COPPER WORKS & 13 & 1,570 & $6,521,082.06$ & 9.24 & 76.44 \\
\hline SOUND PROPE11ER SERVICES LAKE UNION & 5 & 3,282 & $4,981,110.59$ & 7.06 & 83.50 \\
\hline BOEING COMMERCIAL AIRPLANE PLANT 2 & 15 & $2,165,994$ & $2,966,925.06$ & 4.21 & 87.70 \\
\hline SOUND PROPELLER SERVICES SOUTH PARK & 15 & 1,540 & $2,843362.71$ & 4.03 & 91.73 \\
\hline SEATTLE STEEL INC. & 3 & 44,100 & $1,395,724.49$ & 1.98 & 93.71 \\
\hline WESTERN STEEL CASTING CO. & 13 & 9,000 & $1,062,167.62$ & 1.51 & 95.22 \\
\hline WESCOR GRAPHICS CORP. & 9 & 175,830 & $624,489.76$ & 0.89 & 96.10 \\
\hline ASKO PROCESSING INC. & 5 & 212,114 & $508,357.89$ & 0.72 & 96.82 \\
\hline Top 10 facility totals & - & $2,630,549$ & $68,299,288.08$ & 96.82 & 96.82 \\
\hline All facility totals $(\mathrm{n}=113$ ) & - & $8,978,347$ & $70,539,262.74$ & 100.00 & 100.00 \\
\hline
\end{tabular}


To explore whether gentrification potentially had an influence on industrial location, and therefore the formation of environmental inequality, we identified facilities with a triangle that did not report emissions or exist in 1990. In other words, triangles represent new facility locations across Seattle's geography after 1990. Figure 5 dichotomises our 15 clusters into a gentrifying or non-gentrifying trajectory. In the 19 years after 1990 during our study period, 59 new facilities or emissions were reported to the TRI. Only 13 appeared in a gentrifying area while 46 emerged in the non-gentrifying sections of the city. The historically industrial north central part of the city known locally as Ballard hosted 12 TRI facilities in 1990. The area attracted only 11 new facilities over the 19 years after 1990. Conversely, 33 new or relocated facilities began operating in clusters 13 and 15 while only two appeared around Lake Union's 'replacement' cluster 5, four in the downtown 'redevelopment' clusters 9 and 10, and four on Harbor Island.

\section{Discussion}

Seattle's urban geography and riskscape underwent a significant transformation from 1990 to 2009. The city experienced a dramatic postindustrial shift as it continued a move away from manufacturing employment. This deindustrialisation helped most of the environmental conditions across the city become convincingly cleaner and greener. Likewise, the city's professional and managerial workers increased from 36 to $52 \%$ while educational attainment improved from less than 38 to $54 \%$ with a college degree. Median household incomes also increased by nearly $8 \%$ and poverty decreased slightly. Property values nearly doubled and rents increased by $\$ 200$ a month. Such transformations earned the Emerald City a third place ranking among urban areas advancing the 'new economy' behind only San Francisco, CA and Austin, TX (Atkinson and Gottlieb, 2001). But these citywide summaries, like the portrayal of average environmental or economic inequalities, overlook the extreme cases and a closer analysis of variation across clusters and trends among the five gentrification categories sheds new light onto Seattle's stratified social geography and riskscape.

\subsection{Economic and property stratification}

First, among the 15 clusters identified across Seattle, the difference between median household income in the richest Seattle cluster and the poorest in 1990 was $\$ 147,307$. But by 2009 , the gap reached $\$ 192,625$; an increase of $\$ 45,318$. This trend reveals the rapid income inequality growth in a deindustrialising Seattle. Also in 1990, the largest gap in median house value separated clusters 7 and 9 by $\$ 738,564$ but in 2009, the gap between the highest property strata in cluster 7 and the lowest in cluster 14 was $\$ 665,356$. However, there was a substantial gap across clusters in the accumulated wealth embedded in home values. Houses in cluster 13, 14, and 15 held only 73 to $76 \%$ of the value of the median Seattle home. Clusters 13 and 15 joined the 14th cluster in the bottom strata of Seattle house values; all located in the remaining industrialised areas of the city.

Conversely, the lowest property strata in 1990 were clusters 9 and 11 where median house values were $\$ 15,357$ and $\$ 73,598$. However, cluster 9 is composed of only eight CBGs and only one had housing at the beginning of our study period. By 2009, these areas north and east of downtown saw median house value increase by $\$ 592,939$ and $\$ 413,453$. This represents a 3,861 and $561 \%$ change respectively. These gains in an area commonly called Belltown outpaced all other Seattle clusters resulting in house values in 
clusters 9 and 11 carrying 136 and $108 \%$ of the median value of all Seattle homes. Such a dramatic shift exemplifies the rent gap thesis (Smith, 1979; also see Gibson, 2004).

Second, similar patterns are seen among the five gentrification aggregation categories. Consolidation clusters (high social status, income, home values, and ownership rates) had a median household income of $\$ 95,552$ in 1990 and increased by $26 \%$ to reach $\$ 120,693$ by 2009 . This category held the highest median household income throughout the study period. While median house value grew by only $56 \%$, consolidation clusters remained the highest property strata with median house values of $\$ 483,026$ in 1990 and $\$ 754,311$ in 2009.

Transition clusters are some of the most heterogeneous and dynamic constellations but saw even less growth in median household income; increasing by $17 \%$ from $\$ 46,291$ in 1990 to $\$ 54,102$ in 2009 and remained nearly $\$ 7,000$ below the city average. On the one hand, this transition category of cluster groups combines the University of Washington and its immediate neighbourhoods (cluster 8) with another area composing a large share of the industrial district south of downtown (cluster 15). On the other hand, the transition category included a contiguous cluster of block-groups with a significant Asian influx south of downtown versus a fragmented collection of block-groups in North and West Seattle. Median house values increased by $115 \%$ in transition clusters, more than double that of consolidation clusters, but held only $82 \%$ of the value of the median Seattle home.

Clusters of replacement gentrification are widely dispersed across the city and median household income increased from $\$ 56,923$ in 1990 to $\$ 72,163$ in 2009 ; nearly $\$ 12,000$ above the median household income in the city. This trend can be attributed to growth in young professionals employed in higher-income jobs in the 'new economy' sectors anchored around Lake Union and the University of Washington. Moreover, median house values increased by $95 \%$ from $\$ 247,187$ in 1990 to $\$ 481,411$ in 2009 , which outpaced the average growth rate of $87 \%$ in Seattle. The increase in median home values is a reflection of demand on the part of young urban professionals who value a particular lifestyle aesthetic. For instance, access and proximity to regional transportation routes, mixed land-uses, open spaces and viewsheds are common among the dispersed clusters of replacement gentrification (Morrill, 2008; Morrill and Sommers, 2005; Sommers and Carlson, 2000).

The clusters of core redevelopment gentrification had the lowest median household income among all categories, $\$ 24,179$ in 1990 and $\$ 34,809$ in 2009 , yet, the $44 \%$ increase represented the highest rate of growth in median income among the categories. Similarly, median house value of $\$ 50,302$ in 1990 also was the lowest among all categories, however, by 2009 , median house value skyrocketed by $965 \%$ to $\$ 535,549$ and was second to only consolidation clusters. This trend illustrate the efforts of city officials who, in the 1990s, began focusing attention on redevelopment projects in the downtown core including Westlake Center, Pacific Place and condominium conversions. In effect, these efforts were meant to create upscale housing conditions and supportive retail activities to breathe new life into a seemingly decaying downtown core (Birch, 2002; Gibson, 2003, 2004; Strom, 2008).

The two clusters of displacement gentrification exhibited a $43 \%$ increase in median household income, the second highest rate of growth among the categories of clusters, going from $\$ 56,758$ in 1990 to $\$ 81,414$ by 2009 . Cluster 12 encompasses most of the neighbourhood commonly known as the Central District, a majority-minority Black community that became majority White in our study period. Likewise, cluster 10 dropped 
from $30.38 \%$ Black in 1990 to less than $10 \%$ in 2009. In 1990, the median house value of $\$ 223,921$ in these clusters was below the citywide average of $\$ 239,198$; yet a $133 \%$ increase by 2009 took median house value to $\$ 521,693$, or $117 \%$ of the city average.

The property conflict's micro-geography in Seattle was marked by increasing inequitable development. In short, gentrification transformed the city into a more divided geography of class, and to a lesser extent, by race. Seattle's new socioeconomic geography is characterised by a pattern of clusters highly stratified by occupation, income, and property value. In the broadest stroke, Seattle is dividing between an affluent and highly educated postindustrial workforce (knowledge workers at Microsoft and Amazon) and a south central concentration of mixed, and predominately intermediate industrial and service workforce (the Port, Fishing, and Starbuck server class). Moreover, the remaining burdens of an industrial economy remain in the south central area around the Duwamish River.

\subsection{Some get more environmental protection than others}

Risk inequalities had similar variations across both cluster and gentrification category aggregations. For instance, seven of the city's 10 riskiest air polluters in 1990 were located in the same clusters where minority populations were increasing and economic development lagged behind the rest of the city. Of the city's 58 TRI facilities in 1990, cluster 2 contained two facilities and was burdened by less than $1 \%$ of relative exposure risk; cluster 3 held 12 facilities and experienced nearly $5 \%$ of the city's relative exposure risk; and, cluster 5 was home to seven TRI facilities accounting for $39 \%$ of the relative exposure risk. Meanwhile, clusters 13 and 15 contained 28 of 58 TRI facilities and held $57 \%$ of the city's total relative exposure risk.

In the next decade, Seattle's riskscape not only shrank, but the top 10 facilities for relative exposure risk were more dispersed across the city. By 2000, only 34 facilities in Seattle reported to the TRI and the 10 riskiest facilities were distributed among five instead of three clusters. Cluster 3 contained six facilities and relative exposure risk had dropped to less than $2 \%$; cluster 5 held only three facilities but accounted for $76 \%$ of relative exposure risk; and, cluster 9 had one facility responsible for $7 \%$ of the city's relative exposure risk. The number of facilities present in clusters 13 and 15 decreased and the remaining 16 facilities amounted to $15 \%$ of relative exposure risk in Seattle.

This pattern reversed by 2009 however, and industry's citywide relative exposure risk continued to drop dramatically while concentrating in the south central Duwamish River valley. Clusters 13 and 15 contained 13 of 22 TRI facilities in Seattle that amounted to nearly $84 \%$ of the city's total relative exposure risk. These two clusters also held six of the top 10 riskiest air polluters which totaled $82 \%$ of total relative exposure risk. Moreover, $76 \%$ of industry's relative air toxics exposure risks were attributed to just one facility located in cluster 15 . Of the 113 facilities that reported to the TRI between 1990 and 2009, 60 were located in clusters 13 and 15, and accounted for more than $72 \%$ of the total relative exposure risk. Compare this with cluster 2 where five facilities make up less than $1 \%$ of relative exposure risk; 21 facilities in cluster 3 account for less than $3 \%$ of risk; 14 facilities in cluster 5 represent $24 \%$ of relative exposure risk; or, one facility in cluster 9 that amounts to less than $1 \%$ of relative risk.

We also find unequal patterns in the distribution of relative exposure risk among the gentrification categories. Consolidation clusters hold the wealthiest and most affluent residents in terms of educational attainment, occupational status, median household 
income, and property values. Interestingly, this grouping of clusters contained no TRI facilities or relative exposure risk in any single year or over the duration of our study. On the other hand, relative exposure risk in transition clusters, including clusters 13 and 15 , amounted to $62 \%$ in 1990 and climbed to over $99 \%$ of the citywide total by 2009 .

Relative exposure risk in replacement gentrification clusters totaled 38\% in 1990 but decreased to less than $1 \%$ by 2009 . Core redevelopment clusters had zero relative exposure risk in 1990 but in 2000, one facility accounted for $7 \%$ of the citywide total. However, by 2009 no facilities reported to the TRI and relative exposure risk again was zero. Displacement gentrification clusters, similar to consolidation clusters, contained no TRI facilities and were not burdened by any relative exposure risk at any point in our study period (see Figure 6).

Figure 6 Seattle's riskscape from 1990-2009

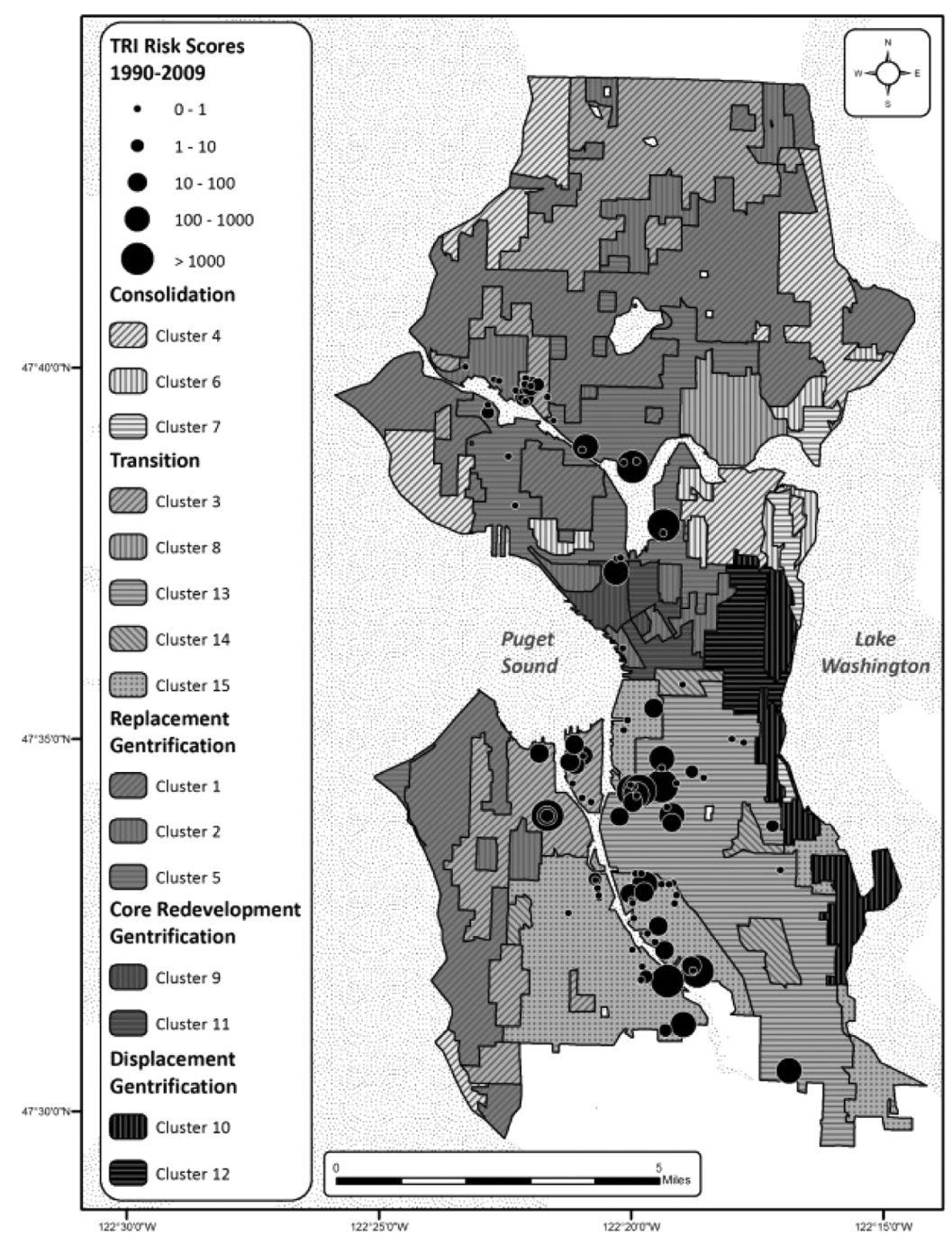


While there is no definitive causal explanation, it is clear that the riskiest industrial facilities and the lowest socioeconomic strata early and late in our longitudinal study converged in the same places. Our analysis illuminated how Seattle deindustrialised on the one hand, but on the other saw the burdens of its remaining industrial facilities fall disproportionately on some of the city's most socially vulnerable. Moreover, the riskiest and most new TRI facility sitings were in clusters 13 and 15 during the 19 years covered by this study. Moreover, this ongoing industrial production of air toxics joins a host of other environmental hazards not covered by the TRI dataset.

According to a recent cumulative health impact assessment study (Gould and Cummings, 2013), the Duwamish Valley zip code (containing clusters 13 and 15) had the highest levels of average diesel particulate matter, the second highest benzene levels, the most confirmed and suspected contaminated sites, the highest childhood asthma hospitalisation rates, and the lowest tree canopy cover. Likewise, in an air pollution cancer risk assessment, researchers (Wu et al., 2009) used data from a monitor located on Beacon Hill in cluster 13 and pollution level monitoring to analyse cancer risks from 10 different sources of hazardous air pollutants (HAPs). Seven of those sources were modelled to produce cancer risks greater than the national standard of 1 in one million extra cancer cases including a collection of unidentified sources estimated to be contributing to more than 15 in one million extra cases of cancer. More recently, a longitudinal air toxics monitoring program in Seattle found higher inhalation cancer risks from data collected at two South Seattle sites compared with four other locations across the city (Wu et al., 2011).

\subsection{Limitations and future research}

Several limitations in our research are worth noting and also provide directions for future research. First, our case study was limited to the city of Seattle. The Emerald City's complex and dynamic urban processes do not occur in a vacuum. Spatial dynamics in the surrounding suburbs, King County, and state policy all have been noted for their contribution to Seattle's geographic patterns. For instance, Washington State is one of the few states with aggressive growth management requirements and while not as stringent as Oregon to the south, many have described a number of distortions created by development limits in the Seattle region (Morrill, 2008).

For instance, one study covering two decades of land cover and land-use change in the Central Puget Sound found that urban lands outside of the region's growth boundaries increased more rapidly than inside those limits. These researchers concluded: "...the intended effect of the Growth Management Act to direct growth to within the urban growth boundaries may not have been accomplished..." (Hepinstall-Cymerman, Coe and Hutyra, 2013, 109). Such temporal and regional land cover studies are important for analysing sustainable development across complex and coupled human and natural systems (Liu et al., 2007) along with attention to regional strategies (Blackwell, 2003).

Second, our research only addresses a part of the complexity of Seattle's dynamic urban geography. We have not included any controls for land-use or zoning patterns in our current research however, a cursory review of the city's comprehensive planning history suggests that the shifts in the riskscape may have been a manifestation of several zoning policy choices. The city adopted the current comprehensive plan titled Toward a Sustainable Seattle in 1994 and 4 years later, a neighbourhood plan for the 
Ballard/Interbay Northend Manufacturing \& Industrial Center (BINMIC) was adopted (SDPD, 2004). BINMIC is historically one of the two major industrial centres of Seattle and this section of the comprehensive plan stated several economic development priorities including:

1 the preservation of land for industrial activities

2 the retention of existing businesses and their expansion

3 better utilise BINMIC subareas for "marine/fishing, high tech, or small manufacturing industrial activities"

4 prioritise water-dependent and industrial uses (emphasis added).

Figure 7 Seattle's changing riskscape from 1990-2009

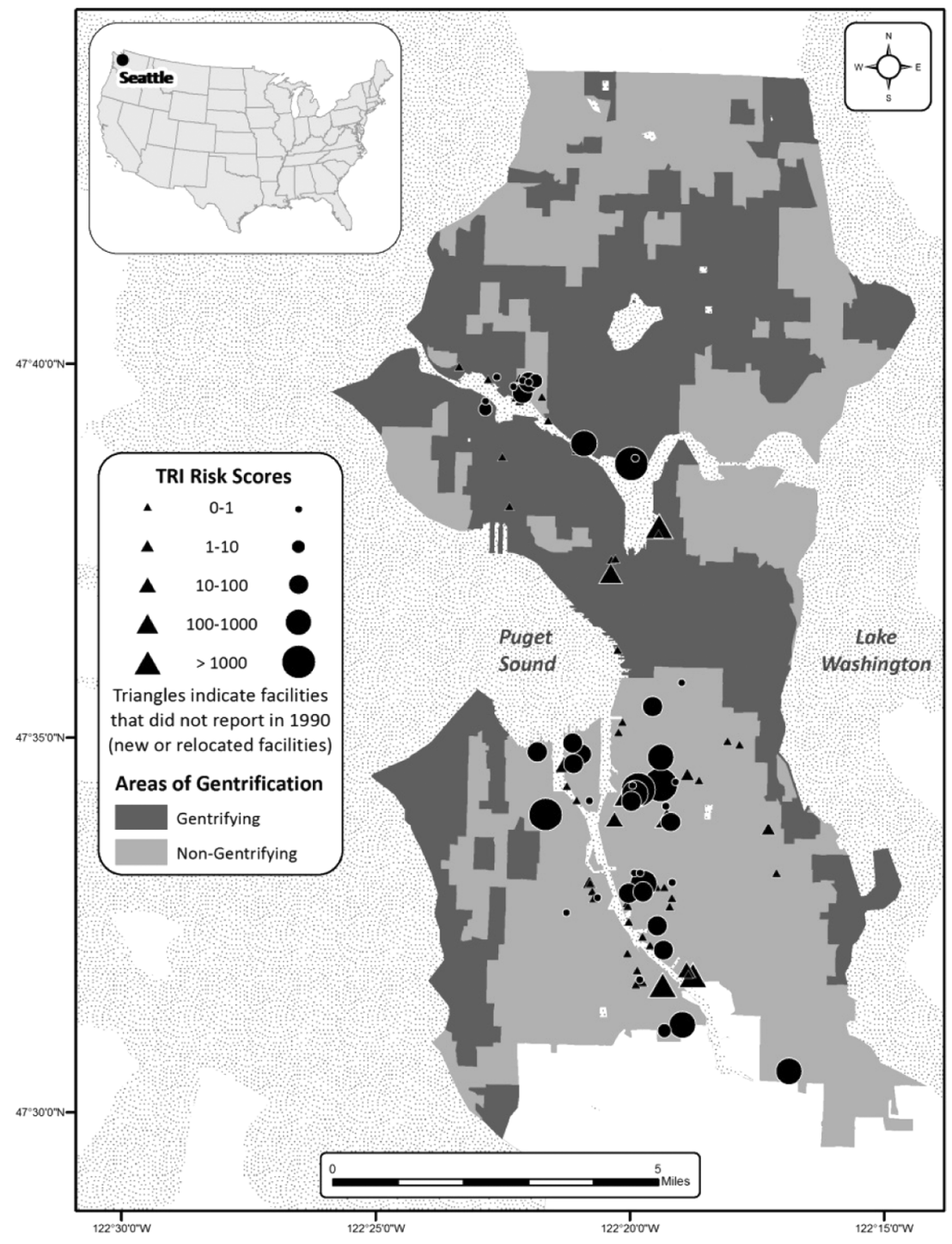


Conversely, the plan for Seattle's second industrial area called the Greater Duwamish Manufacturing/Industrial Center (GDMIC) adopted in 2000 included these priorities:

1 maintaining land for industrial uses

2 facilitating location and expansion of industrial businesses

3 encourage new industrial business development

4 limit the location or expansion of non-industrial uses (SDPD 2004).

Consequently, a higher percentage of permits for the conversion of industrial uses into nonindustrial activities occurred in BINMIC than GDMIC.

In two subareas of BINMIC (North and South), 20 and 27\% of permits, respectively, were industrial conversions to nonindustrial uses. In the Georgetown subarea of GDMIC, $4 \%$ of permit changes were industrial conversions to nonindustrial but in South Park, $63 \%$ of the permits were conversions of nonindustrial activity to industrial uses according to a city study (SDPD, 2007a).

Moreover, despite the comprehensive plan's stated goal to: "Preserve industrial land for industrial uses and protect viable marine and rail-related industries from competing with nonindustrial uses for scarce industrial land" (SDPD, 2004, 69), 15 blocks of industrial zoned land in the South Lake Union neighbourhood were rezoned to 'Seattle Mixed' which aimed to combine residential and commercial uses (SDPD, 2007b). In other words, city policies appeared to abandon industrial activity in South Lake Union, expand new industrial businesses in the GDMIC, and only allow the expansion of existing industries in the BINMIC. Our data in Figure 7 showing Seattle's industrial riskscape shifting from North to South Seattle seems consistent with several planning documents. In sum, this shift of the industrial riskscape appears to be a planned outcome and deserves much more attention that is beyond the scope of this study.

\section{Conclusion}

Our combined application of the environmental science of relative-risk screening and geographic social science in a longitudinal analysis revealed Seattle's complicated yet intersecting trajectories of environmental inequality and socioeconomic stratification. Such historical considerations will be a crucial input in the needed and much larger research task assessing urban sustainability. In fact, we see a rekindled debate about gentrification among urban geographers and economists fractured unproductively along methodological lines. National level analyses primarily rely on census tract measures of gentrification for multiple metropolitan areas resulting in too coarse of a resolution to inform policy effectively. Moreover, it often ignores the significant spatial variation in specific neighbourhoods. Likewise, studies using individual level mobility data to assess gentrification are too granular. Both methods display an over commitment to either a structural model of gentrification processes or the pure agency of behavioural individualism. Our methods detailed here instead paint a picture of how micro-structural analysis can be used to screen for hot spots of both environmental risk sources and socially disruptive gentrification trends. The theory and empirical work in sustainability suffers the same limitations. 
In conclusion, the literature on environmental injustice and health disparities has found that spatial distributions of pollution hazards and socially vulnerable populations cluster together in metropolitan areas. Far fewer studies examine how skewed these exposure riskscapes can be as well as how environmental inequalities are formed. Seattle has been heralded for its leadership in sustainability, but our analysis undermines that reputation. Parts of the city fared poorly in all three dimensions of sustainabilityenvironment, equity, and economy. In fact, environmental and socioeconomic inequality has always been a feature of Seattle's geography (Klingle, 2007), and our methods revealed how the city's pollution exposure risks ebbed and flowed between 1990 and 2009. We also found that the city's neighbourhoods divided more sharply along socioeconomic lines. Finally, we found pollution exposure risk and lower socioeconomic clusters converging in the same place. Seattle's pollution riskscape and urban development burdens have been skewed towards some of the city's most socially vulnerable residents. A more just sustainability instead of a gentrified one for the Emerald City will require more political and policy attention mitigating inequitable development and environmental injustice.

\section{Acknowledgements}

This research was supported by Western Washington University's Research and Sponsored Programs and we want to thank participants in Seattle University's Just Sustainability: Hope for the Commons conference session on Northwest Stories, Phil Thompson, and two anonymous reviewers for their helpful support and suggestions.

\section{References}

Abel, T. (2008) 'Skewed riskscapes and environmental injustice: a case study of metropolitan St. Louis', Environmental Management, Vol. 42, No. 2, pp.232-248.

Abel, T. and White, J. (2011) 'Skewed riskscapes and gentrified inequities: environmental exposure disparities in Seattle, Washington', American Journal of Public Health, Vol. 101, No. S1, pp.246-254.

Abu-Lughod, J.L. (1969) 'Testing the theory of social area analysis: the ecology of Cairo, Egypt', American Sociological Review, Vol. 34, No. 2, pp.198-212.

Agyeman, J. (2005) Sustainable Communities and the Challenge of Environmental Justice, New York University Press, New York.

Agyeman, J., Bullard, R.D. and Evans, B. (Eds.) (2003) Just Sustainabilities: Development in an Unequal World, MIT Press, Cambridge, MA.

Aldenderfer, M.S. and Blashfield, R.K. (1984) Cluster Analysis, Sage Publications, Beverly Hills, CA.

Anderton, D.L., Anderson, A.B., Oakes, J.M. and Fraser, M.R. (1994) 'Environmental equity: the demographics of dumping', Demography, Vol. 31, No. 2, pp.229-248.

Ash, M. and Fetter, T.R. (2004) 'Who lives on the wrong side of the environmental tracks? Evidence from the EPA's risk-screening environmental indicators model', Social Science Quarterly, Vol. 85, No. 2, pp.441-462.

Atkinson, A. (1996) 'Developing indicators of sustainable community: lessons from sustainable Seattle', Environmental Impact Assessment Review, Vol. 16, No. 4, pp.337-350.

Atkinson, R. (2003) 'Introduction: misunderstood savior or vengeful wrecker? The many meanings and problems of gentrification', Urban Studies, Vol. 40, No. 12, pp.2343-2350. 
Atkinson, R.D. and Gottlieb, P.D. (2001) The Metropolitan New Economy Index, Progressive Policy Institute and Center for Regional Economic Issues, Washington, DC.

Bates, L.K. and Zapata, M.A. (2013) 'Revisiting equity: the HUD sustainable communities initiative.', Progressive Planning, Winter, No. 194, pp.14-17.

Bell, D. (1973) The Coming of Postindustrial Society: A Venture in Social Forecasting, Basic Books, New York, NY.

Berry, B.J.L. (1971) 'Introduction: the logic and limitations of comparative factorial ecology', Economic Geography, Vol. 47, No. 2, pp.209-219.

Berry, B.J.L. (1985) 'Islands of Renewal in Seas of Decay', in Peterson, P. E. (Ed.): The New Urban Reality, The Brookings Institution, Washington, DC.

Berry, B.J.L. and Rees, P.H. (1969) 'The factorial ecology of Calcutta.' The American Journal of Sociology, Vo. 74, No. 5, pp.445-491.

Birch, E.L. (2002) 'Having a longer view on downtown living', Journal of the American Planning Association, Vol. 68, No. 1, pp.5-21.

Blackwell, A.G. (2000) 'Promoting equitable development', Indiana Law Review, Vol. 34, pp.1273-1290.

Blackwell, A.G. (2003) 'It takes a region', Fordham Urban Law Journal, Vol. 31, No. 5, pp.13031319.

Blackwell, A.G. and Bell, J. (2005) 'Equitable development for a stronger nation: lessons from the field', in Briggs, X.D.S. and Wilson, W.J. (Eds.): Race and Housing Choice in Metropolitan America, Brookings Institution Press, Washington, DC, pp.289-309.

Boer, J.T., Pastor, M., Sadd, J.L. and Snyder, L.D. (1997) 'Is there environmental racism? The demographics of hazardous waste in Los Angeles County', Social Science Quarterly, Vol. 78, No. 4, pp.793-810.

Bondi, L. (1999) 'Gender, class and gentrification: enriching the debate', Environment and Planning D: Society and Space, Vol. 17, No. 3, pp.261-282.

Boone, C.G. and Modarres, A. (1999) 'Creating a toxic neighborhood in Los Angeles County: a historical examination of environmental inequity', Urban Affairs Review, Vol. 35, No. 2, pp.163-187.

Bostic, R. and Martin, R. (2003) 'Black home-owners as a gentrifying force? neighborhood dynamics in the context of minority', Urban Studies, Vol. 40, No. 12, pp.2427-2449.

Boström, M. (2012) 'A missing pillar? Challenges in theorizing and practicing social sustainability: introduction to the special issue', Sustainability: Science, Practice, \& Policy, Vol. 8, No. 1, pp.3-14.

Bouwes, N.W., Hassur, S.M. and Shapiro, M.D. (2001) Empowerment Through Risk-related Information: EPA's Risk Screening Environmental Indicators Project, Political Economy Research Institute, Amherst, MA.

Bowen, W.M., Salling, M.J., Haynes, K.E. and Cyran, E.J. (1995) 'Toward environmental justice: spatial equity in Ohio and Cleveland', Annals of the Association of American Geographers, Vol. 85, No. 4, pp.641-663.

Bramley, G., Dempsey, N., Power, S., Brown, C. and Watkins, D. (2009) 'Urban form and social sustainability: the role of density and housing type', Environment and Planning B, Vol. 36, pp.30-48.

Bramley, G. and Power, S. (2009) 'Urban form and social sustainability: the role of density and housing type,' Environment and Planning B, Vol. 36, pp.30-48.

Bryant, B. and Mohai, P. (Ed.) (1992) Race and the Incidence of Environmental Hazards: A Time for Discourse, Westview Press, Boulder, CO.

Bullard, R. (1983) 'Solid waste sites and the black Houston community', Sociological Inquiry, Vol. 53, pp.273-88.

Bullard, R. (1990) Dumping in Dixie: Race, Class, and Environmental Quality, Westview Press, Boulder, CO. 
Bullard, R. (1994) 'Overcoming racism in environmental decisionmaking', Environment, Vol. 36, No. 4, pp.10-17.

Burke, L. (1993) 'Race and environmental equity: a geographic analysis in Los Angeles', Geographic Information Systems, October, Vol. 3, No. 9, pp.44-50.

Burton, E. (2000) 'The compact city: just or just compact? A preliminary analysis', Urban Studies, Vol. 37, No. 11, pp.1969-2001.

Cadwallader, M. (1996) Urban Geography: An Analytical Approach, Prentice Hall, Upper Saddle River, NJ.

Campbell, S. (1996) 'Green cities, growing cities, just cities? Urban planning and the contradictions of sustainable development', Journal of the American Planning Association, Vol. 62, No. 3, pp.296-312.

Chakraborty, J. and Bosman, M.M. (Eds.) (2010) Spatial and Environmental Injustice in an American Metropolis: A Study of Tampa Bay, Florida, Cambria Press, Amherst, NY.

Cohen, A. (2007) 'Home, wage gap remains', Seattle P-I, September 11, http://www.seattlepi. $\mathrm{com} /$ business/article/Home-wage-gap-widens-1249357.php. Accessed May 31, 2015.

Connelly, S. (2007) 'Mapping sustainable development as a contested concept', Local Environment, Vol. 12, No. 3, pp.259-278.

Cuthill, M. (2010) 'Strengthening the 'social' in sustainable development: developing a conceptual framework for social sustainability in a rapid urban growth region in Australia', Sustainable Development, Vol. 18, No. 6, pp.362-373.

Cutter, S. and Solecki, W.D. (1996) 'Setting environmental justice in space and place: acute and chronic airborne toxic releases in the Southeastern United States', Urban Geography, Vol. 17, No. 5, pp.380-399.

Davidson, P. and Anderton, D.L. (2000) Demographics of dumping II: a national environmental equity survey and the distribution of hazardous materials handlers', Demography, Vol. 37, No. 4, pp.461-466.

Dempsey, N., Brown, C. and Bramley, G. (2012) 'The key to sustainable urban development in UK cities? The influence of density on social sustainability', Progress in Planning, Vol. 77, pp.89-141.

Dobson, A. (1998) Justice and the Environment: Conceptions of Environmental Sustainability, Oxford University Press, New York, NY.

Dobson, A. (2003) 'Social justice and environmental sustainability: ne'er the twain shall meet', in Agyeman, J., Bullard, R.D. and Evans, B. (Eds.): Just Sustainabilities: Development in an Unequal World, MIT Press, Cambridge, MA, pp.83-98.

Downey, L. (2006) 'Environmental racial inequality in Detroit', Social Forces, Vol. 85, No. 2, pp.771-796.

Downey, L., Dubois, S., Hawkins, B. and Walker, M. (2008) 'Environmental inequality in metropolitan America', Organization \& Environment, Vol. 21, No. 3, pp.270-294.

Downey, L. and Hawkins, B. (2008) 'Race, income, and environmental inequality in the United States', Sociological Perspectives, Vol. 51, No. 4, pp.759-781.

Ellen, I.G. and O'Regan, K.M. (2011) 'How low income neighborhoods change: entry, exit, and enhancement', Regional Science and Urban Economics, Vol. 41, No. 2, pp.89-87.

Eley, C. (2010) 'Equitable development: untangling the web of urban development through collaborative problem solving', Sustain: A Journal of Environmental and Sustainability Issues, Vol. 21, No. Fall/Winter, pp.3-12.

Eley, C. (2013) Putting sustainability within reach of environmental justice communities. http://blog.epa.gov/ej/2013/12/putting-sustainability-within-reach-of-environmental-justicecommunities/. Accessed March 16, 2015.

Elkington, J. (1998) Cannibals with Forks: The Triple Bottom Line of 21st Century Business, New Society Publishers, Stony Creek, CT. 
Elliott, J.R. and Frickel, S. (2013) 'The historical nature of cities: a study of urbanization and hazardous waste accumulation', American Sociological Review, Vol. 78, No. 4, pp.521-543.

Fischer, C.S., Stockmayer, G., Stiles, J. and Hout, M. (2004) 'Distinguishing the geographic levels and social dimensions of US metropolitan segregation, 1960-2000', Demography, Vol. 41, pp.37-59.

Florida, R. (2002) The Rise of the Creative Class, Basic Books, New York.

Florida, R., Matheson, Z., Adler, P. and Brydges, T. (2014) The Divided City and the Shape of the New Metropolis, Martin Prosperity Institute, Rotman School of Management, University of Toronto, Toronto.

Gibson, T.A. (2003) 'The trope of the organic city: discourses of decay and rebirth in downtown Seattle', Space \& Culture, Vol. 6, No. 4, pp.429-448.

Gibson, T.A. (2004) Securing the Spectacular City: The Politics of Revitalization and Homelessness in Downtown Seattle, Lexington Books, Lanham, MD.

Gilbert, A. and Chakraborty, J. (2011) 'Using geographically weighted regression for environmental justice analysis: cumulative cancer risks from air toxics in Florida', Social Science Research, Vol. 40, No. 1, pp.273-286.

Goldman, B. (1991) The Truth about Where You Live: An Atlas for Action on Toxins and Mortality, Times Books/Random House, New York, NY.

Goldman, B. and Fitton, L. (1994) Toxic Wastes and Race Revisited: An Update of the 1987 Report on the Racial and Socioeconomic Characteristics of Communities with Hazardous Waste Sites, Center for Policy Alternatives, Washington, DC.

Gould, L. and Cummings, B.J. (2013) Duwamish Valley Cumulative Health Impacts Analysis, Just Health Action and Duwamish River Cleanup Coalition/Technical Advisory Group, Seattle, WA.

Hammel, D. and Wyle, E. (1996) 'A model for identifying gentrified areas with census data', Urban Geography, Vol. 17, No. 3, pp.248-268.

Hamnett, C. (1991) 'The blind men and the elephant: The explanation of gentrification', Transactions of the Institute of British Geographers, Vol. 16, No. 2, pp.173-189.

Hamnett, C. (2003) 'Gentrification and the middle class remaking of Inner London, 1961-2001', Urban Studies, Vol. 40, No. 12, pp.2401-2426.

Hamnett, C. and Whitelegg, D. (2007) 'Loft conversion and gentrification in London: from industrial to postindustrial land use', Environment and Planning A, Vol. 39, No. 1, pp.106124.

Harvey, D. (1989) The Condition of Postmodernity, Basil Blackwell, Oxford.

Haynes, K.E. (1971) 'Spatial change in urban structure: alternative approaches to ecological dynamics', Economic Geography, Vol. 47, No. 2, pp.324-335.

Heidkamp, C. P. and Lucas, S. (2006) 'Finding the gentrification frontier using census data: the case of Portland, ME', Urban Geography, Vol. 27, No. 2, pp.101-125.

Hepinstall-Cymerman, J., Coe, S. and Hutyra, L.R. (2013) 'Urban growth patterns and growth management boundaries in the Central Puget Sound, Washington, 1986-2007', Urban Ecosystems, Vol. 16, No. 1, pp.109-129.

Hudspeth, N. (2003) 'Gentrification and decline in Chicago: defining neighborhood change with census data', Proceedings of Interpreting Neighborhood Change Conference, April 4, University of Illinois at Chicago.

Hurley, A. (1995) Environmental Inequalities: Class, Race, and Industrial Pollution in Gary, Indiana, 1945-1980, The University of North Carolina Press, Chapel Hill, NC.

Janson, C.-G. (1980) 'Factorial social ecology: An attempt at summary and evaluation', Annual Review of Sociology, Vol. 6, pp.433-456.

Jenks, M. and Jones, C. (Eds.) (2010) Dimensions of the Sustainable City, Springer, London.

Karlenzig, W. (2007) How Green is Your City? The Sustainlane US City Rankings, New Society Publishers, Gabriola Island, BC. 
Karlenzeig, W. (2008) 'What makes today's green city?', in Birch, E. and Wachter, S. (Eds.): Growing Greener Cities: Urban Sustainability in the Twenty-First Century, University of Pennsylvania Press, Philadelphia, PA.

Kennedy, M. and Leonard, P. (2001) Dealing with Neighborhood Change: A Primer on Gentrification and Policy Choices, Brookings Institution Center on Urban and Metropolitan Policy and PolicyLink, Washington, DC.

Kershaw, S., Gower, S., Rinner, C. and Campbell, M. (2013) 'Identifying inequitable exposure to toxic air pollution in racialized and low-income neighbourhoods to support pollution prevention', Geospatial Health, Vol. 7, No. 2, pp.265-278.

Kim, J. and Mueller, C.W. (1978) Factor Analysis: Statistical Methods and Practical Issues, Sage Publications, Beverly Hills, CA.

Klingle, M. (2007) Emerald City: An Environmental History of Seattle, Yale University Press, New Haven.

Krieg, E.J. (1995) 'A socio-historical interpretation of toxic waste sites: the case of Greater Boston', American Journal of Economics and Sociology, Vol. 54, No. 1, pp.1-14.

Lattin, J.M., Carroll, J.D. and Green, P.E. (2003) Analyzing Multivariate Data, Thomson Brooks/Cole, Pacific Grove, CA.

Lees, L., Slater, T. and Wyly, E.K. (2008) Gentrification, Routledge/Taylor \& Francis, New York.

Ley, D. (1981) 'Inner-city revitalization in Canada: a Vancouver case study, Canadian Geographer, Vol. 25, No. 2, pp.124-148.

Ley, D. (1996) The New Middle Class and the Remaking of the Central City, Oxford University Press, Oxford, New York.

Liu, J., Dietz, T., Carpenter, S.R., Folke, C., Alberti, M., Redman, C.L., Schneider, S.H., Ostrom, E., Pell, A.N., Lubchenco, J., Taylor, W.W., Ouyang, Z., Deadman, P., Kratz, T. and Provencher, W. (2007) 'Coupled human and natural systems', AMBIO: A Journal of the Human Environment, Vol. 36, No. 8, pp.639-649.

Liu, N. (2015) 'Working in partnership for equitable development', Tools and Strategies for Making a Visible Difference in Communities, Proceedings of the Equitable Development Workshop, Baltimore, MD. http://www.newpartners.org/2015/program/equitabledevelopment, Accessed 30 May, 2015.

Lyon, L. and Driskell, R. (2011) The Community in Urban Society, Waveland Press, Long Grove, IL.

McGee Jr., H.W. (2007) 'Seattle's central district, 1990-2006: integration or displacement', Urban Lawyer, Vol. 39, No. 2, pp.167-256.

McKinnish, T., Walsh, R. and White T.K. (2010) 'Who gentrifies low-income neighborhoods?', Journal of Urban Economics, Vol. 67, No. 2, pp.180-193.

McManus, P. (1996) Contested terrains: politics, stories and discourses of sustainability', Environmental Politics, Vol. 5, No. 1, pp.48-73.

Mitchell, G. (1996) 'Problems and fundamentals of sustainable development indicators', Sustainable Development, Vol. 4, No. 1, pp.1-11.

Mitchell, J.T., Thomas, D.S.K. and Cutter, S.L. (1999) 'Dumping in Dixie revisited: the evolution of environmental injustices in South Carolina', Social Science Quarterly, Vol. 80, No. 2, pp.229-243.

Mohai, P. and Saha, R. (2006) 'Reassessing racial and socioeconomic disparities in environmental justice research', Demography, Vol. 43, No. 2, pp.383-399.

Mohai, P. and Saha, R. (2007) 'Racial inequality in the distribution of hazardous waste: A nationallevel reassessment', Social Problems, Vol. 54, No. 3, pp.343-370.

Morello-Frosch, R., Pastor Jr., M., Porras, C. and Sadd, J. (2002) 'Environmental justice and regional inequality in southern California: implications for future research', Environmental Health Perspectives, Vol. 110, No. S2, pp.149-154. 
Morello-Frosch, R., Pastor, M. and Sadd, J. (2001) 'Environmental justice and Southern California's "riskscape": the distribution of air toxics exposures and health risks among diverse communities', Urban Affairs Review, Vol. 36, No. 4, pp.551-578.

Morrill, R. (2004) Gentrification in Seattle. Central Puget Sound Real Estate Research Report 81, Spring.

Morrill, R. (2008) 'Gentrification, Class, and Growth Management in Seattle, 1990-2000', in Pomeroy, G. and Webster, G. (Eds.): Global Perspectives on Urbanization, University Press of America, Lanham, MD.

Morrill, R. and Sommers, P. (2005) 'Seattle as a digital city: unexpected or inevitable?', Canadian Journal of Regional Science, Vol. 28, No. 2, pp.349-368.

National Research Council (2004) Air Quality Management in the United States, National Academies Press, Washington, DC.

Neumann, C.M., Forman, D.L. and Rothlein, J.E. (1998) 'Hazard screening of chemical releases and environmental equity analysis of populations proximate to toxic release inventory facilities in Oregon', Environmental Health Perspectives, Vol. 106, No. 4, pp.217-226.

Oakes, J.M., Anderton, D.L. and Anderson, A.B. (1996) 'A longitudinal analysis of environmental equity in communities with hazardous waste facilities', Social Science Research, Vol. 25, No. 2, pp.125-148.

Pacione, M. (2005) Urban Geography: A Global Perspective, 2nd ed., Routledge, London, New York.

Pastor, M., Morello-Frosch, R. and Sadd, J.L. (2005) 'The air is always cleaner on the other side: Race, space, and ambient air toxics exposures in California', Journal of Urban Affairs, Vol. 27, No. 2, pp.127-148.

Pastor, M., Sadd, J.L. and Hipp, J. (2001) 'Which came first? Toxic facilities, minority move-in, and environmental justice', Journal of Urban Affairs, Vol. 23, No. 1, pp.1-21.

Pastor, M., Sadd, J.L. and Morello-Frosch, R. (2004) 'Waiting to inhale: the demographics of toxic air release facilities in 21 st-century California', Social Science Quarterly, Vol. 85, No. 2, pp.420-440.

Pellow, D.N. (2000) 'Environmental inequality formation: toward a theory of environmental injustice', The American Behavioral Scientist, Vol. 43, No. 4, pp.581-600.

Pollock, P.H. and Vittas, M.E. (1995) 'Who bears the burden of environmental pollution? Race, ethnicity, and environmental equity in Florida', Social Science Quarterly, Vol. 76, pp.295310.

Portney, K. (2003) Taking Sustainable Cities Seriously: Economic Development, the Environment, and Quality of Life in American Cities, MIT Press, Cambridge, MA.

Pulido, L. (2000) 'Rethinking environmental racism: white privilege and urban development in Southern California', Annals of the American Association of Geographers, Vol. 90, No. 1, pp.12-40.

Pulido, L., Sidawi, S. and Vos, R.O. (1996) 'An archaeology of environmental racism in Los Angeles', Urban Geography, Vol. 17, pp.419-439.

Rhodes, E. and Mayo, J. (2006) 'Only 9 areas in King County left for middle-income buyers', Seattle Times, July 16, 2006, at B1.

Ringquist, E.J. (2005). 'Assessing evidence of environmental inequities: a meta-analysis', Journal of Policy Analysis and Management, Vol. 24, No. 2, pp.223-247.

Sadd, J.L., Pastor Jr., M., Boer, J,T. and Snyder, L.D. (1999) "Every breath you take": the demographics of toxic air releases in Southern California', Economic Development Quarterly, Vol. 13, No. 2, pp.107-123.

Sadd, J.L., Pastor, M., Morello-Frosch, R., Scoggins, J. and Jesdale, B. (2011) 'Playing it safe: Assessing cumulative impact and social vulnerability through an environmental justice screening method in the south coast air basin, California', International Journal of Environmental Research and Public Health, Vol. 8, No. 5, pp.1441-1459. 
Saha, R. (2009) 'Empirical research on local government sustainability efforts in the USA: gaps in the current literature', Local Environment, Vol. 14, No. 1, pp.17-30.

Saha, D. and Paterson, R.G. (2008) 'Local government efforts to promote the "Three Es" of sustainable development survey in medium to large cities in the United States', Journal of Planning Education and Research, Vol. 28, No. 1, pp.21-37.

Sanders, J.C. (2010) Seattle and the Roots of Urban Sustainability: Inventing Ecotopia, University of Pittsburgh Press, Pittsburgh, PA.

Savitz, A. (2013) The Triple Bottom Line: How Today's Best-Run Companies are Achieving Economic, Social and Environmental Success-and How You Can Too, John Wiley \& Sons, San Francisco, CA.

Schmid, C. and Tagashira, K. (1964) 'Ecological and demographic indices: a methodological analysis', Demography, Vol. 1, No. 1, pp.194-211.

Schmidt, C.W. (2003) 'The risk where you live', Environmental Health Perspectives, Vol. 111, No. 7, p.A404.

Seattle Department of Planning and Development (SDPD). (2004). Seattle's Comprehensive Plan. http://www.seattle.gov/dpd/cityplanning/completeprojectslist/comprehensiveplan/whatwhy/def ault.htm. Accessed March 16, 2015.

Seattle Department of Planning and Development (SDPD). (2007a). Seattle's industrial lands background report. http://www.seattle.gov/dpd/vault/cs/groups/pan/@pan/documents/web informational/s048202.pdf. Accessed March 16, 2015.

Seattle Department of Planning and Development (SDPD). (2007b). South Lake Union Urban Center Neighborhood Plan.http://www.seattle.gov/dpd/cs/groups/pan/@pan/documents/web informational/dpds021899.pdf. Accessed March 16, 2015.

Shapiro, M.D. (2005) 'Equity and information: information regulation, environmental justice, and risks from toxic chemicals', Journal of Policy Analysis and Management, Vol. 24, No. 2, pp.373-399.

Shevky, E. and Bell, W. (1955) Social Area Analysis: Theory, Illustrative Application, and Computational Procedures, Stanford University Press, Stanford, CA.

Sicotte, D. and Swanson, S. (2007) 'Whose risk in Philadelphia? Proximity to unequally hazardous industrial facilities', Social Science Quarterly, Vol. 88, No. 2, pp.515-534.

Smith, N. (1979) 'Toward a theory of gentrification: A back to the city movement by capital, not people', Journal of the American Planning Association, Vol. 45, No. 4, pp.538-548.

Smith, N. (1987) 'Gentrification and the rent gap', Annals of the Association of American geographers, Vol. 77, No. 3, pp.462-465.

Smith, N. (1996) The New Urban Frontier: Gentrification and the Revanchist City, Routledge, London.

Smith, N. (2000) 'Gentrification', in Johnston, R.J., Gregory, D., Pratt, G. and Watts, M. (Eds.): The Dictionary of Human Geography, 4th ed., Blackwell, Oxford.

Sommers, P. and Carlson, D. (2000) The New Economy in Metropolitan Seattle: High Tech Firm Location Decisions within the Metropolitan Landscape, The Brookings Institution Center on Urban and Metropolitan Affairs, Washington, DC.

Strom, E. (2008) 'Rethinking the politics of downtown development', Journal of Urban Affairs, Vol. 30, No. 1, pp.37-61.

Stroud, E. (1999) 'Troubled waters in Ecotopia: environmental racism in Portland, Oregon', Radical History Review, Vol. 74, pp.65-95.

Szasz, A. and Meuser, M. (2000) 'Unintended, Inexorable: the production of environmental inequalities in Santa Clara Country, California', American Behavioral Scientist, Vol. 43, No. 4, pp.602-632.

Toffel, M.W. and Marshall, J.D. (2004) 'Improving environmental performance assessment: a comparative analysis of weighting methods used to evaluate chemical release inventories', Journal of Industrial Ecology, Vol. 8, No. 1-2, pp.143-172. 
United Church of Christ (UCC) (1987) Toxic Wastes and Race: A National Report on the Racial and Socioeconomic Characteristics of Communities with Hazardous Waste Sites, Commission for Racial Justice, New York, NY.

United States Department of Commerce. (1994) Geographic Areas Reference Manual, Economics and Statistics Administration, Division of Geography, Bureau of the Census, Washington, DC.

United States Environmental Protection Agency. (2003) EPA presents Seattle with Climate Protection Award, Environmental Protection Agency, Washington, DC. http://yosemite. epa.gov/opa/admpress.nsf/d96f984dfb3ff7718525735900400c29/fe5a811418ee16a3852570cb 0075e25c!opendocument. (July 13, 2014).

United States Environmental Protection Agency (EPA). (2015) Equitable development, environmental justice and smart growth. 14th Annual New Partners for Smart Growth Conference. Baltimore, MD, January 29-31.

United States Government Accounting Office (GAO). (1983) Siting of Hazardous Waste Landfills and their Correlation with Racial and Economic Status of Surrounding Communities, United States Government Accounting Office, Washington, DC.

Vifell, A.C. and Soneryd, L. (2012) 'Organizing matters: how 'the social dimension'gets lost in sustainability projects’, Sustainable Development, Vol. 20, No. 1, pp.18-27.

Vigdor, J.L., Massey, D.S. and Rivlin, A.M. (2002) 'Does gentrification harm the poor?', Brookings-Wharton Papers on Urban Affairs, pp.133-182.

Vojnovic, I. (2013) 'Advancing toward urban sustainability: the pursuit of equity', in Vojnovic, I. (Ed.): Urban Sustainability: A Global Perspective, Michigan State University Press, East Lansing, MI, pp.2-34.

Warner, K. (2000) 'Linking local sustainability initiatives with environmental justice', Local Environment: The International Journal of Justice and Sustainability, Vol. 7, No. 1, pp.35-47.

Willard, B. (2012) The New Sustainability Advantage: Seven Business Case Benefits of a Triple Bottom Line, New Society Publishers, Gabriola Island.

Williams, C.C. and Millington, A.C. (2004) 'The diverse and contested meanings of sustainable development', The Geographical Journal, Vol. 170, No. 2, pp.99-104.

World Commission on Environment and Development. (1987) Our Common Future, Oxford University Press, Oxford, UK.

Wu, C., Liu, L.-J.S., Cullen, A., Westberg, H. and Williamson, J. (2011) 'Spatial-temporal and cancer risk assessment of selected hazardous air pollutants in Seattle', Environment International, Vol. 37, No. 1, pp.11-17.

Wu, C., Wu, S., Wu, Y., Cullen, A. C., Larson, T. V., Williamson, J. and Liu, L.-J.S. (2009) 'Cancer risk assessment of selected hazardous air pollutants in Seattle', Environment International, Vol. 35, No. 3, pp.516-522.

Wyly, E.K. (1999) 'Continuity and change in the restless urban landscape', Economic Geography, Vol. 75, No. 4, pp.309-338.

Wyly, E.K. and Hammel, D.J. (1999) 'Islands of decay in seas of renewal: housing policy and the resurgence of gentrification', Housing Policy Debate, Vol. 10, No. 4, pp.711-771.

Wyly, E.K. and Hammel, D.J. (2004) 'Gentrification, segregation, and discrimination in the American urban system', Environment and Planning A, Vol. 36, pp.1215-1242.

Yandle, T. and Burton, D. (1996) 'Reexamining environmental justice: a statistical analysis of historical hazardous waste landfill siting patterns in metropolitan Texas', Social Science Quarterly, Vol. 77, No. 3, pp.477-492.

Zeemering, E.S. (2009) 'What does sustainability mean to city officials?', Urban Affairs Review, Vol. 45, No. 2, pp.247-273. 